\title{
INCOME AND WEALTH OF OLDER AMERICAN HOUSEHOLDS: \\ MODELING ISSUES FOR PUBLIC POLICY ANALYSIS
}

\author{
Alan L. Gustman \\ F. Thomas Juster
}

Working Paper No. 4996

\section{NATIONAL BUREAU OF ECONOMIC RESEARCH 1050 Massachusetts Avenue Cambridge, MA 02138 January 1995}

The authors are grateful to the National Academy of Sciences and to the National Institute On Aging for research support. Helpful comments by Gary Engelhardt, Anna Lusardi, Andrew Samwick, Jonathan Skinner and Steve Venti are very much appreciated. This paper is part of NBER's research programs in Aging and Labor Studies. Any opinions expressed are those of the authors and not those of the National Bureau of Economic Research. 
NBER Working Paper \#4996

January 1995

\title{
INCOME AND WEALTH OF OLDER \\ AMERICAN HOUSEHOLDS: \\ MODELING ISSUES FOR PUBLIC \\ POLICY ANALYSIS
}

\begin{abstract}
This paper evaluates the extent to which current knowledge of retirement, savings, pension and related behavior is sufficient for determining the effects of major policy initiatives on the incomes and wealth of the aged population of the United States. Data are presented from two new surveys, the Health and Retirement Study and the Asset and Health Dynamics Among the Oldest Old Survey, describing the distributions of the major components of income and wealth to be explained by these behavioral models. The data suggest that the amount of wealth held by the older population has been severely understated in earlier surveys. Disagreements and inconsistencies in models of savings indicate that there is no agreed upon behavioral model upon which to base policy analysis. Similar problems characterize the pension literature. Most strikingly, central features of these three major branches of behavioral analysis are mutually inconsistent. Although there are important linkages among the behaviors determining retirement, savings and pension outcomes, research in each area ignores or misspecifies the related behavior from other areas. Consequently, significant advances are required before we can confidently predict the effects of contemplated changes in policies on income and wealth in retirement.
\end{abstract}
Alan L. Gustman
F. Thomas Juster
Department of Economics
Survey Research Center
Dartmouth College
Hanover, NH 03755-3514
and NBER
Institute for Social Research
The University of Michigan
Ann Arbor, MI 48106-1248 


\section{Introduction}

This paper is concerned with the economic behavior determining the income and wealth of older American households, and with our capacity to analyze the effects of public policies determining their income and wealth. It begins by providing a structure for relating the outcomes of interest to leading behavioral models. This is followed by descriptive statistics indicating the relative importance of the major components of income and wealth. The paper then assesses the current state of models, describing what is known about the behavior of individuals and firms that affects income and wealth determination, what is not known, and what kinds of models and data are needed to do an adequate job of understanding income and wealth outcomes and the effects of policies meant to influence these outcomes. The final part of the paper considers an array of policy changes that might be expected to influence the income and wealth of older households.

\section{Conceptual Overview}

Figure 1 indicates the major components of income and wealth of the older population, and the elements of behavior of individuals, of markets, and in the public sector that determine these income and wealth outcomes. Box, A represents a matrix of income and wealth outcomes. The outcomes are delineated by type of income, but the matrix is meant to represent the full dimension of time and cohort effects, as well as the various sources of heterogeneity in outcomes. Box B lists the behavioral decision. They include the basic decisions of labor supply and savings, as well as other behaviors that must receive attention for a full understanding of wealth and income. Below that in Box $\mathrm{C}$ is an array of market determined outcomes that are taken as exogenous to the individual, such as the features of the pension plan, determined by the employer subject to market constraints. The right hand box, D, lists some of the basic categories for the policies that will be discussed. The arrows indicate the joint determination of the elements listed under each of these categories.

A central focus of the paper is the behavior of individuals and the efforts of firms to accommodate the behavior and preferences of individuals. Our aim is to determine whether the 


\section{Figure 1:}

\section{Framework For Analysis From The Perspective of Individual's Decisions}
A. Components of
Income And Wealth
1. Earnings
2. Social Security
3. Pensions
4. Financial and Other Assets
5. Housing Assets
6. Public Transfers

B. Elements of Individual Behavior Determining Outcome
1. Labor Supply
2. Savings
3. Pensions
4. Family Transfers
5. Insurance
6. Demand for Home Ownership
7. Demand for Alternate Living Arrangements
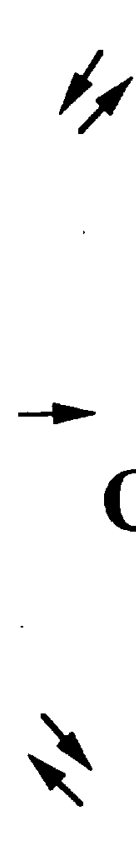

1. Wages

2. Interest

3. Inflation

4. Pension Rules

5. Price of Insurance (Health,Life,Other)

6. Housing

7. Price of Health Services
1. Social Security Policies

2. Tax Policies

3. Pension Policies

4. Employment Policies

5. Health Insurance Policies

6. Other Public Transfer Policies 
analyses of the various dimensions of behavior indicated in Figure 1 are sufficiently reliable to support policy analysis, and if not what additional research is required to improve the quality of the available behavioral models. As a result of our analysis, we conclude that among the key dimensions of behavior, we have greater confidence in the retirement models for use in policy analysis than in models of saving or pensions. Models of savings and pensions continue to wrestle with behavioral issues that remain unresolved at a more fundamental level than are the questions that confront retirement modeling. But we also find that none of the models of behavior in any one area takes sufficient account of the behavior along other dimensions. These behaviors may interact in important ways, and most of the literature ignores these interactions.

\section{Components Of Income And Wealth Of Older Households}

To measure the importance of the major components of income and wealth, we begin with descriptive data on income and wealth outcomes for recent cohorts. The relevant data include the Current Population Survey (CPS), where we use 1992 income data analyzed by Grad (1994); the Survey of Income and Program Participation (SIPP), where we use 1991 wealth data analyzed by Poterba, Venti and Wise (1994); the Health and Retirement Survey (HRS), where we use income data from 1991 and wealth data from 1992; and the Survey of Asset and Health Dynamics of the Oldest Old (AHEAD), where we use income data from 1992 and wealth data from 1993.

These datasets are complementary. CPS covers the entire age range, as does SIPP, but the income and wealth data from these surveys, especially the wealth data, tend to be under-estimates relative to either HRS or AHEAD; new survey technologies have been introduced in both HRS and AHEAD that result in substantially smaller biases resulting from missing data components. But while HRS and AHEAD appear to have somewhat higher qual ity data, they represent particular cohorts and do not include a full range of age distributions. HRS includes the birth cohorts of 1931-1941, while AHEAD includes the birth cohorts of 1923 and before. 
The data in Table 1 provide a useful overview of the sources of income and wealth for households who are in a transition stage between work and retirement--those 65 to 69 years of age. For these households, earnings comprise a little under $30 \%$ of total income; Social Security comprises another $30 \%$, while pensions and income from assets each comprise a bit under $20 \%$ of total income. On the asset side, if both Social Security income flows and pension income flows are capitalized, the two comprise a little over half of total wealth, with the other half coming from conventionally measured net worth--the sum of financial and other assets and housing equity.

From these data we can see the extent of the under-estimation problem in the measurement of assets: Table 1 is based on data from SIPP, where conventionally defined net worth (the total of financial and other assets plus housing equity) for these 65-69 year olds has a mean value in 1991 of roughly $\$ 150,000$; SIPP households aged $55-64$, a younger age group that typically has smaller net worth than the 65-69 group, has a mean 1991 total of about $\$ 140,000$. In contrast, the HRS data on net worth, for households between 51 and 61 where asset holdings would be expected to be smaller still, has a mean 1992 value of approximately $\$ 240,000$--a figure that is approximately $60 \%$ larger than the Table 1 estimate. And the AHEAD net worth data, for an age group much older than the SIPP 65-69 year olds and who would therefore be expected to have a much lower asset level, has a 1993 mean value for conventionally defined net worth of approximately $\$ 170,000$--higher than the 65 69 year olds in Table 1. 
Table 1: Sources of Money Income and Wealth For 65 to 69 Year Olds.

\begin{tabular}{||l|l|l||}
\hline & $\begin{array}{l}\text { Share of Aggregate Income of } \\
\text { Aged Units. }\end{array}$ & $\begin{array}{l}\text { Average Wealth From } \\
\text { Indicated Source As A } \\
\text { Percent Of Total Net Worth }\end{array}$ \\
\hline Earnings & $28.9 \%$ & \\
\hline Social Security & 29.9 & $31.9 \%$ \\
\hline Pensions & 18.8 & 19.9 \\
\hline Financial And Other Assets & 18.7 & 27.8 \\
\hline Public Assistance & .7 & \\
\hline Other Income & 3.1 & \\
\hline Housing & & 20.8 \\
\hline Total & 100.1 & 100.4 \\
\hline
\end{tabular}

Source: Income percentages are from Grad (1994, Table VII.1). Grad's figures are based on the 1992 CPS. Wealth percentages are computed from Poterba, Venti and Wise (1994, Table 1). Their data are from the Survey Of Income and Program Participation and are reported for 1991.

Note that the data in Table 1 are missing some components. For example, one would generally prefer to include imputed income from housing equity in the income definition, and might well include imputed values for services provided by Medicare and Medicaid. The wealth data might include present discounted values for Supplemental Security Income, other welfare payments, and transfers. According to Hurd (1990a, Table 18) these are not negligible sources of income or wealth. It is also worth noting that including the capitalized value of future Social Security or pension benefits as part of wealth, while appropriately reflecting the consumption value of these assets, represents a relatively inflexible source of economic support. To some extent that is also true of housing equity, although here the inflexibility lies as much in consumer choice as in legal or institutional constraints. But it is certainly clear that Social Security wealth cannot be bought and sold, nor can pension wealth; and while housing equity can be bought or sold, most households appear to treat housing equity as a fixed and immutable fact of economic circumstances, not an asset that can be used to smooth consumption flows in future years.

An important feature of both income and wealth is their heterogeneity among households. 
Households are always heterogeneous in the types and amounts of income and wealth that they own, but that heterogeneity is likely to grow as households move into older age groups. And both distributions, especially the wealth distributions, are highly skewed in that medians are small relative to mean values.

The heterogeneity of the income sources received by older households is documented in Tables 2 and 3. Table 2 shows the detailed structure of income from HRS (for age groups in their 50s), and for AHEAD (for age groups in their 70s and 80s). Total household income is of course substantially larger for the HRS sample than for AHEAD, due partly to cohort differences in earnings but mainly due to age differences. The HRS households are about 30 years younger than the AHEAD households aged 80 and over, and thus there has been 30 years worth of economy-wide improvement for the HRS cohort compared to the AHEAD $80+$ cohort. In addition, the AHEAD data reflect the fact that the replacement of earnings by the sum of Social Security benefits and pensions is at much lower than a one-to-one ratio for most households.

The income component data in Table 2 do not contain any surprises. Earnings are the dominant source of income for the HRS cohorts in their 50s, while pensions, especially Social Security, are the dominant source of income for households in the AHEAD cohorts. Earnings are relatively unimportant for households in the AHEAD age range, and the pattern of private pension income, which is about 3 times as high among AHEAD cohorts in the 70-74 year old group as in the 85 and older group, is explainable both by cohort differences and by the growing incidence of widowhood among older households in the AHEAD cohorts. Finally, earnings of household members other than the HRS or AHEAD survey respondent and spouse are an important source of family income, especially for the oldest AHEAD cohorts (those 85 years of age or older). 
Table 2: INCOME COMPONENTS, HRS and AHEAD (000 dollars)

\begin{tabular}{|c|c|c|c|c|c|c|}
\hline \multirow[b]{2}{*}{ Income Source } & \multicolumn{2}{|c|}{$\begin{array}{l}\text { HRS: } 1991 \text { Data } \\
\text { Age of HH Head }\end{array}$} & \multicolumn{4}{|c|}{$\begin{array}{c}\text { AHEAD: } 1992 \text { Data } \\
\text { Age of HH Head }\end{array}$} \\
\hline & $51-55$ & $56-61$ & $70-74$ & $75-79$ & $80-84$ & $85+$ \\
\hline Earnings & 40.6 & 32.4 & 4.0 & 1.5 & 1.0 & 0.2 \\
\hline Pensions & 1.0 & 2.8 & 16.6 & 14.9 & 12.4 & 10.4 \\
\hline Soc. Security & 0.1 & 0.2 & 10.2 & 10.4 & 9.4 & 8.2 \\
\hline Private Pension & 0.9 & 2.6 & 6.4 & 4.5 & 3.0 & 2.2 \\
\hline Capital Income & 5.1 & 5.9 & 2.1 & 2.9 & 2.6 & 1.8 \\
\hline Disability & 0.4 & 0.6 & \multirow[b]{4}{*}{1.1} & \multirow[b]{4}{*}{0.8} & \multirow[b]{4}{*}{0.7} & \multirow[b]{4}{*}{0.8} \\
\hline Welfare & 0.3 & 0.3 & & & & \\
\hline Unemployment & 0.4 & 0.3 & & & & \\
\hline Other & 0.2 & 0.2 & & & & \\
\hline TOTAL & 48.0 & $\overline{42.4}$ & $24.8^{*}$ & $21.9 *$ & $17.8 *$ & $15.7^{*}$ \\
\hline $\begin{array}{l}\mathrm{HH} \text { Members other than } \\
\mathrm{R} \text { or Spouse }\end{array}$ & 4.9 & 4.7 & 3.0 & 2.8 & 3.7 & 5.0 \\
\hline TOTAL & 52.9 & 47.1 & 27.8 & 24.7 & 21.5 & 20.7 \\
\hline
\end{tabular}

*Derived from an independent question, not from summing the components. The sum of components is generally lower than the above total for technical reasons (mainly the use of unfolding brackets for the total income question).

The heterogeneity of income components for the AHEAD cohort shows up very clearly in Table 3, which contains sample means, means for households with positive income in a particular category, and percentile distributions. Not surprisingly, hardly any AHEAD age groups have wage income, all the way up to the 90 th percentile. Equally surprising to some, capital income is zero for the entire lower half of the AHEAD distribution, amounts to only a few hundred dollars for AHEAD cohorts up as high as the 75th percentile, and only amounting to a substantial sum when we get around the 90th percentile, where the amounts are several thousand dollars rather than several hundred dollars. The only income sources that are at all widely distributed among AHEAD households are Social Security income, which virtually everyone receives, and pension income, which is received by the upper half of the distribution in the younger age cohorts and by the upper quarter in the older age cohorts. For each age category and percentile, pension income exceeds Social Security income in the AHEAD sample for only one age cohort and one of the percentiles shown--the 90th percentile for the 70-74 year olds. As we note later, this pattern looks as if it will be a bit 
different when the HRS cohorts get to be in the AHEAD age range, although that depends in part on changes over time in the proportion of jobs providing pensions and in the proportion of pensions that contain survivors' rights.

Table 3: Components of Income, AHEAD Sample

\begin{tabular}{|c|c|c|c|c|c|c|c|}
\hline Age & Mean for & Mean if $>$ & \multicolumn{5}{|c|}{ Percentiles } \\
\hline Group & Sample & zero & 10 & 25 & 50 & 75 & 90 \\
\hline \multicolumn{8}{|c|}{ A: Wage Income } \\
\hline $70-74$ & 4,059 & 18,989 & 0 & 0 & 0 & 0 & 8,000 \\
\hline $75-79$ & 1,463 & 14,934 & 0 & 0 & 0 & 0 & 0 \\
\hline $80-84$ & 1,013 & 15,586 & $\mathbf{0}$ & $\overline{0}$ & 0 & 0 & 0 \\
\hline $85+$ & 162 & 12,776 & 0 & 0 & 0 & $\overline{0}$ & 0 \\
\hline \multicolumn{8}{|c|}{ B: Capital Income } \\
\hline $70-74$ & 2,089 & 6,923 & 0 & 0 & $\overline{0}$ & 240 & 4,620 \\
\hline $75-79$ & 2,941 & 9,396 & 0 & 0 & 0 & 318 & 4,800 \\
\hline $80-84$ & 2,605 & 9,182 & 0 & 0 & 0 & 300 & 5,000 \\
\hline $85+$ & 1,798 & 6,987 & 0 & 0 & 0 & 0 & 3,600 \\
\hline \multicolumn{8}{|c|}{ Social Security Income } \\
\hline $70-74$ & 10,246 & 10,259 & 4,440 & 6,516 & 9,480 & 13,000 & 15,900 \\
\hline $75-79$ & 10,374 & 10,390 & 4,800 & 6,420 & 9,210 & 12,696 & 16,308 \\
\hline $80-84$ & $9, \overline{384}$ & 9,411 & 4,608 & 6,000 & 8,208 & 11,724 & 14,712 \\
\hline $85+$ & 8,248 & 8,276 & 4,236 & 5,550 & 7,578 & 9,492 & 12,000 \\
\hline \multicolumn{8}{|c|}{ D: Pension Income } \\
\hline $70-74$ & 6,404 & 10,660 & 0 & 0 & 2,680 & 7,218 & 16,080 \\
\hline $7 \overline{75-79}$ & 4,539 & 8,647 & 0 & 0 & 1,200 & 4,644 & 11,604 \\
\hline $80-\overline{84}$ & 2,964 & 6,714 & 0 & 0 & 0 & 2,964 & 9,540 \\
\hline $85+$ & 2,247 & 6,366 & 0 & 0 & 0 & 2,247 & 6,900 \\
\hline \multicolumn{8}{|c|}{ E: Other Income } \\
\hline $70-74$ & 1,109 & 6,126 & 0 & 0 & $\begin{array}{l}0 \\
\end{array}$ & 0 & 2,400 \\
\hline $75-\overline{79}$ & 773 & 4,652 & 0 & 0 & $\overline{0}$ & $\overline{0}$ & 1,861 \\
\hline $80-84$ & 740 & 4,076 & 0 & 0 & 0 & 0 & 1,861 \\
\hline $85+$ & 773 & 4,189 & 0 & 0 & 0 & 0 & 2,160 \\
\hline \multicolumn{8}{|c|}{ F: Other Family Members' Income } \\
\hline $70-74$ & 3,026 & 19,870 & 0 & 0 & 0 & 0 & 13,162 \\
\hline $75-79$ & 2,839 & 19,719 & 0 & 0 & $\overline{0}$ & 0 & 13,162 \\
\hline $80-84$ & 3,689 & $22,37 \overline{9}$ & 0 & 0 & 0 & 0 & 13,162 \\
\hline $85+$ & 4,979 & 21,386 & 0 & .0 & 0 & 6,571 & 13,162 \\
\hline \multicolumn{8}{|c|}{ G: TOTAL FAMILYINCOME } \\
\hline $70-74$ & \multicolumn{2}{|c|}{$\frac{27,778}{24754}$} & 8,280 & 12,460 & 19,304 & 29,723 & 49,200 \\
\hline $75-79$ & \multirow{2}{*}{\multicolumn{2}{|c|}{$\begin{array}{l}24,754 \\
21,515\end{array}$}} & 7,428 & 10,374 & 16,539 & 25,004 & 42,374 \\
\hline $80-84$ & & & 6,528 & 9,398 & 13,992 & 22,561 & 38,352 \\
\hline $85+$ & \multicolumn{2}{|c|}{20,723} & 6,564 & 8,400 & 13,000 & 20,476 & 35,064 \\
\hline
\end{tabular}


The heterogeneity in economic status among older households is even more pronounced when we examine the data on net worth. Appendix A1-A7 contain estimates of total net worth, net worth in the form of housing equity, and net worth less housing equity for various HRS and AHEAD classifications of households. For HRS, we divide the sample into couples, single men and single women (Table A-1), by racial/ethnic groups including blacks, hispanics and whites plus others (Table A-2), and by 1991 income (Table A-3). For the AHEAD sample, we show data for couples and singles in Table A-4 (Total Net Worth) and A-5 (Net Worth Excluding Home Equity), as well as for racial/ethnic groups in Tables A-6 (Total Net Worth) and A-7 (Net Worth Excluding Home Equity). For the AHEAD data, we show separate estimates for four age groups -- 70-74, 75-79, 80-84, and 85 and up.

The principal message from this set of net worth tables is that wealth is highly unevenly distributed among the older population: both in the HRS and AHEAD samples, married couples have substantially higher levels of wealth, even after implicit correction for household size, than single men or single women; the disparities are substantially larger for net worth less housing equity than for total net worth, since housing equity itself is somewhat more evenly distributed than most other assets; minority households have substantially fewer assets than whites by an order of magnitude of four or five to one in mean values, and an order of magnitude more like ten to one for net worth less housing equity.

For the AHEAD data, there are of course substantial differences by age group as well as by family composition and racial/ethnic group. In general, older households have smaller net worth, other things equal, although the differences by age are surprisingly small for couples up through the age of 80-84. The most striking disparities in the AHEAD data are those shown by the tabulations of net worth excluding home equity, both by family composition and by racial/ethnic group, divided according to age group. For the family composition data, fully half the single women had net financial assets excluding home equity of under $\$ 10,000$ regardless of age--the $70-74$ group and the 
$85+$ group have just about the same (minimal) assets. Single men are a little better off, but fully half of this group has under $\$ 20,000$ of net worth excluding home equity. For couples, in contrast, the median net worth excluding home equity is a little over $\$ 55,000$ for the $70-74$ age group, and is still about $\$ 20,000$ for the $85+$ age group. As would be expected, there are some very wealthy subcategories of households in the sample: AHEAD households in the 90th percentile among couples have over $\$ 400,000$ of net worth excluding home equity, and almost $\$ 600,000$ net worth in total, for those with heads age 70-74. Even for those couples aged 85 and up, AHEAD households have over a quarter of a million dollars in net worth excluding home equity at the 90th percentile, and over $\$ 400,000$ of total net worth. For minority households in the AHEAD sample, it is essentially correct that fully half of all black and hispanic households have close to zero net worth excluding home equity, regardless of age, and even at the 75th percentile, neither black nor hispanic households have as much as $\$ 20,000$ of net worth excluding home equity in any of the AHEAD age groups. To all intents and purposes, most minority households can be thought of as having negligible financial asset holdings in old age.

\section{Income Distribution Issues}

The income and wealth data show substantial disparity among households, and the disparities appear to be a bit greater for households 70 and over than for others. One way to look at issues of income distribution is to examine the economic circumstances associated with private pensions.

Two alternative models might be contrasted. In one model, the existence of a private pension, since it involves a cost to the employer, provided less current income. On that model, households with substantial pensions would have had less current income than other comparably situated households, and during retirement would be expected to have more pension income than others, but less income from capital and from Social Security benefits.

In an alternative model, the market is such that jobs that carry pensions are also apt to carry higher current income than other jobs, perhaps because only those with high wage rates want 
pensions, given the tax advantages of pensions and the low Social Security replacement rate for high wage jobs. Hence households with pensions will have more favorable economic circumstances generally as they move toward retirement. On that model, households with substantial pension income would also be expected to have substantial capital income relative to other households (because of their higher current income while working), and to have higher Social Security benefits (again because of their more favorable current income while working). In short, an important issue is: Do households with jobs that carry substantial pensions have offsetting differences in other sources of retirement income, or do the differences tend to cumulate--those with pensions having more of other forms of retirement income as well?

Tables $4 a$ and $4 b$ show comparisons for both the HRS and the AHEAD sample. For HRS, we contrast households in which both respondent and spouse have jobs with pension rights, households where one has a job with pension rights and the other has a non-pension job, and households where neither has a job with pension rights although both have jobs. We also show data for singles who work, with and without pensions on their job. We tabulate current earnings for these HRS households, and also tabulate capital income. For the AHEAD households, we divide the sample into households receiving some pension income versus those receiving none, and tabulate pension income, Social Security benefits, capital income and total income for each of the AHEAD age groups.

It is clear enough from the data, especially the AHEAD data, that favorable economic circumstances cumulate rather than offset. Both for the HRS age range and for the various AHEAD age ranges, households either expecting or receiving pension income have substantially higher nonpension income (capital income and job earnings in the case of HRS households, Social Security benefits and capital income in the case of AHEAD households). For the AHEAD sample, where the differences are clearest and the analysis least ambiguous, households receiving pension income have close to twice as much total income as other households. 
Table 4a: Pension, Social Security, and Capital Income by Whether Pension Income and Age, AHEAD HOUSEHOLDS

NOTE: All categories weighted by the AHEAD household population weight.

\begin{tabular}{|c|c|c|c|c|c|c|}
\hline $\begin{array}{l}\text { Whether } \\
\text { Pension } \\
\text { Income }\end{array}$ & $\begin{array}{l}\text { \% Having } \\
\text { Pension } \\
\text { Income }\end{array}$ & $\begin{array}{l}\text { Mean Pension } \\
\text { Income }\end{array}$ & $\begin{array}{l}\text { Mean Soc Sec } \\
\text { lncome }\end{array}$ & $\begin{array}{l}\text { \% Having } \\
\text { Capital } \\
\text { Income }\end{array}$ & $\begin{array}{l}\text { Mean Capital } \\
\text { Income }\end{array}$ & $\begin{array}{l}\text { Mean Total } \\
\text { Income* }\end{array}$ \\
\hline \multicolumn{7}{|c|}{ ALL CASES $(\mathrm{N}=5457)$} \\
\hline Yes & 50.6 & $\$ 8,915$ & $\$ 10,981$ & $39 \%$ & $\$ 2,869$ & $\$ 25,908$ \\
\hline No & 49.4 & $-0-$ & $\$ 8,532$ & $20 \%$ & $\$ 1,722$ & $\$ 15,507$ \\
\hline \multicolumn{7}{|c|}{ Age 70-74 $(N=1818)$} \\
\hline Yes & 58.3 & $\$ 10,340$ & $\$ 10,964$ & $37 \%$ & $\$ 2,290$ & $\$ 28,237$ \\
\hline$\overline{\text { No }}$ & 41.7 & -0 & $\$ 8,815$ & $20 \%$ & $\$ 1,979$ & $\$ 18,053$ \\
\hline \multicolumn{7}{|c|}{ Age $75-79(\mathrm{~N}=1415)$} \\
\hline Yes & 50.0 & $\$ 8,504$ & $\$ 11,385$ & $43 \%$ & $\$ 3,727$ & $\$ 26,626$ \\
\hline No & 50.0 & $-0-$ & $\$ 9,041$ & $19 \%$ & $\$ 1,795$ & $\$ 16,047$ \\
\hline \multicolumn{7}{|c|}{ Age 80-84 $(N=1120)$} \\
\hline Yes & 42.3 & $\$ 6,803$ & $\$ 10,404$ & $39 \%$ & $\$ 3,443$ & $\$ 21,092$ \\
\hline No & 57.7 & $-0-$ & $\$ 8,200$ & $20 \%$ & $\$ 1,866$ & $\$ 14,011$ \\
\hline \multicolumn{7}{|c|}{ Age 85+ $(N=794)$} \\
\hline Yes & 34.1 & $\$ 6,099$ & $\$ 9,011$ & $39 \%$ & $\$ 2,773$ & $\$ 19,064$ \\
\hline No & 65.9 & $-0-$ & $\$ 7,202$ & $19 \%$ & $\$ 1,131$ & $\$ 11,148$ \\
\hline
\end{tabular}

* "Mean Income" is income of respondent and spouse only.

Table 4b: Earnings and Capital Income by Pension Status, HRS HOUSEHOLDS Working for Pay and Not Self-Employed*

\begin{tabular}{|c|c|c|c|c|}
\hline Whether Has & & 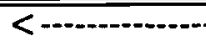 & Mean Values ( $\$ C$ & 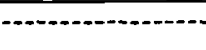 \\
\hline Pension & $\%$ of Cases & Eamings & Capital Income & Total Income \\
\hline \multicolumn{5}{|c|}{ SINGLES } \\
\hline Yes & 66.8 & $\$ 29.0$ & $\$ 2.4$ & $\$ 37.1$ \\
\hline No & 33.2 & $\$ 14.9$ & $\$ 1.3$ & $\$ 23.3$ \\
\hline \multicolumn{5}{|c|}{ COUPLES } \\
\hline Both Have & 57.1 & $\$ 64.4$ & $\$ 4.0$ & $\$ 75.0$ \\
\hline One Has & 34.6 & $\$ 49.7$ & $\$ 2.9$ & $\$ 62.1$ \\
\hline Neither Has & 8.3 & $\$ 36.7$ & $\$ 5.3$ & $\$ 49.2$ \\
\hline
\end{tabular}

*Both spouses working in Couple households.

Finally, we show a mapping of the relationship between health status and both income and wealth for HRS households (see Appendix, Figures A1-4). Although these data come from a crosssection and therefore are not helpful on questions of causality, the strength of the relationship between 
health and wealth or health and income is quite remarkable, whether measured by relationships involving means or medians. For the net worth measure, couples where both spouses are either in excellent or very good health have net worth in the area of $\$ 400,000$, while households where both spouses are in fair or poor health tend to have net worth of less than a quarter of that. These differences are even sharper for median net worth, and are almost as large for either mean or median household income. Interestingly enough, if there is any difference in the relationship between household financial variables and health for the male or female spouse, it appears that the health of the female spouse is more systematically related to the household's financial well-being than the health of the male spouse.

\section{Models Of Individual And Firm Behavior Explaining Retirement Income And Wealth}

This section considers briefly what we know and do not know about the dimensions of behavior that are central to an understanding of how policies affect retirement incomes and retirement wealth. The discussion covers labor supply decisions, savings behavior, pension plan determination, and the determination of Social Security income at the level of the individual. Also discussed are the behaviors determining family structures and transfers, and the demand for housing.

\section{A. Income From Earnings Based On Labor Supply Decisions}

To project earnings, it is necessary to explain patterns of labor force participation among older workers on jobs offering different wage rates.' Thus an important part of the approach to understanding the determination of the earnings of older individuals, and the effects of public policies on earnings, is to apply a conventional intertemporal model of labor supply, and to use the labor supply outcome together with the wage to determine earnings.

The conventional model for explaining labor force behavior into retirement is dynamic.

${ }^{1}$ In examining behavior from the perspective of the individual, we will take the wage offer at a given age and tenure as exogenous to the individual's decision in older age. 
Subject to a series of constraints, including the wage offer for work when fully employed, the wage offer for part-time work and the rate of pension accrual (including its option value), as well as the corresponding rate of accrual in Social Security benefits and other factors, the individual reaches a decision on whether to continue working full-time, part-time or not at all. In this approach, the parameters of a utility function are estimated so as to maximize the likelihood of observing the sequence of outcomes realized for each individual, subject to the constraints created by the elements of the opportunity set. ${ }^{2}$

Different versions of the model has proved capable of explaining some major features of data reflecting labor supply of older individuals and their retirement. These include the spikes in the retirement hazard, most commonly at age 65 , but at 55 for some and 62 for others. The models also explain the fact that two thirds of retirees proceed directly from full-time work to retirement, the relatively short duration of partial retirement, the coincidence of retirement decisions by husbands and wives, and some (about a quarter) of that portion of the trend to earlier retirement observed from 1970 through the mid 1980 s. $^{3}$

Recent contributions have been made on a number of dimensions, adding to the richness of the dynamic specification, considering reaction to risk as well as expected values, incorporating interdependence of decisions at the level of the family, entertaining the possibility of retirement behavior that is influenced by liquidity constraints, and enriching the array of nonfinancial considerations employed in the model.

${ }^{2}$ Fields and Mitchell (1984); Burtless and Moffitt (1984, 1985); Gustman and Steinmeier (1986a); Berkovec and Stern (1991); Rust (1990), Stock and Wise (1990a and 1990b), Lumsdaine, Stock and Wise (1990, 1992a, 1992b).

${ }^{3}$ See Gustman and Steinmeier (1986a, 1994) and Anderson, Gustman and Steinmeier (1994).

${ }^{4}$ For recent studies elaborating on the dynamic structure of the dependent variable, see Blau (1994) and Peracchi and Welch (1994). For models of retirement using a rich set of dynamic flows in the context of a dynamic programming model, see, for example, Rust (1990), Berkovec and Stern (1991). For an analysis that incorporates the effects of incomplete annuity markets, borrowing constraints and incomplete markets for health insurance on labor market behavior, see Rust and Phalen (1993). For inclusion in the opportunity set of the discontinuities from the option value of the 
Despite all of this work, there are many basic questions about retirement behavior that have not yet been addressed. Although we have made important progress in improving the dynamic and stochastic structures of retirement models, considerable work remains before we incorporate in a single setting the full array of behaviors in relation to uncertainty, mistakes, revisions, surprises, and random shocks. For example, Rust (1990) and Berkovec and Stern (1991), omit any consideration of the relation of pension incentives to labor market outcomes, either focusing on the portion of the sample without a pension, or simply ignoring the existence of the pension. In estimating these models, it will be important to measure pension incentives using data collected from worker descriptions as well as from firms. ${ }^{5}$

Findings based on the HRS by Brown (1993) suggest that some workers who accept an offer of a retirement window from one employer actually continue working, sometimes accepting another full-time job. This implies that some elements of mobility models (e.g, as in Allen, Clark and McDermed, 1992a; Gustman and Steinmeier, 1993b) will have to be incorporated with in retirement models that, to date, have exclusively analyzed the departure from a full-time job as if it involved a

pension, see Stock and Wise (1990a and b) and Lumsdaine, Stock and Wise (1990). For family retirement models see Hurd (1990b) and Gustman and Steinmeier (1994). For models that include further information on nonwage aspects of emṕloyment, see Gustman and Steinmeier (1986b) and Hurd and McGarry (1993a).

SIn order to make estimation tractable, researchers have made a number of simplifications reducing the complexity of the dependent variable specification, the detail of the opportunity set, the complexity of the dynamic decisions allowed and the richness of the econometric specification. Some inadequacies in models estimated to date have reflected limitations in the available data sets. One fundamental choice has been between nationally representative data sets that include only respondent provided descriptions of a few elements of the pension plan, such as studies based on data from the Retirement History Study or the National Longitudinal Study of Older Men, or choosing data sets with highly detailed employer-provided descriptions of pensions, but with very narrow samples, including only the employees of a few firms. Thus studies using employer-provided plan descriptions have been confined to analyzing the decision to leave the firm from which the pension data had been obtained; subsequent employment experience was not observed and could not be analyzed. Nor in the studies focusing on the analysis of behavior in a few firms have there been data on family characteristics and labor market activity, or detailed information on the health status of the worker. Health is simply included under the random term. Only recently have we begun to see retirement analysis based on nationally representative data that includes information from employer provided pension plan descriptions (Samwick, 1993a). But the model specification remains highly simplified compared to some of the structural analyses now available in the literature. 
substantial cessation of economic activity. Brown's findings are especially troublesome for studies that define retirement as exit from the payroll of a single firm. What is required for the models of Lumsdaine, Stock and Wise (1992a and b), for example, is to incorporate wages from work after retirement, as in the study of retirement from the air force by Ausink and Wise (1993), but allowing for the joint choices of work or retirement.

One of the tests that is natural to impose on available studies is whether a model explains satisfactorily major social trends and policy outcomes. The weakness of available labor supply and retirement models is reflected in the limited ability of such models to explain satisfactorily the trend to earlier retirement. For example, for the period from 1970 through the mid 1980's, simple decomposition analyses that would explain the trend on the basis of changes in the composition of workers' demographic characteristics or employment, cannot successfully explain the trend to earlier retirement (Ruhm, 1992, Anderson, Gustman and Steinmeier, 1994). Using structural retirement models, some of the trend (about a quarter of the trend in the 1970's and 1980's) can be explained by the changes in pensions and Social Security. ${ }^{6}$ We still do not have enough confidence in the implied substitution and income effects from these models to have a firm handle on the causes of these trends. ${ }^{7}$ Also disturbing in this context are the strong implications of the pension literature that

\footnotetext{
${ }^{6}$ Anderson, Gustman and Steinmeier (1994) attribute about a quarter of the trend to the sharp decline observed in pension early and normal retirement dates, and to the reduced effect of continued work on the Social Security benefit in the 1980's compared to the incentives in the early 1970's. This type of analysis does not answer why the pension incentives were changed as they were, and leaves unexplained the other three fourths of the change in retirement behavior.

${ }^{7}$ One issue that is subject to recent disagreement is the question of whether the trends in retirement are due to trends in incentives and unexpected wealth effects from the start up and revisions of pension plans and Social Security, as implied by the work of Ippolito (1990) and others, or are due to trends in wages differentials and the forces underlying these trends, as implied by Peracchi and Welch (1994). If trends in retirement among older cohorts may be attributed to the effects of unexpected changes in Social Security wealth, then this raises a question. Shouldn't we expect to see the trend cease, as we have, and then strongly reverse itself, as the Social Security system matured and the Congress ceased granting important benefit increases after the 1970s? (Perhaps the flattening of the trend in recent years is just the beginning of a strong reversal; however, it has been eight years since the trend ceased and no strong reversal is yet apparent.) Moreover, if changes in the wage structure due to the decline in relative and real wage of the unskilled account for the trend to earlier retirement, as Peracchi and Welch (1994) argue, why do we see the same trend to
} 
pensions are designed to meet the preferences of covered workers (Gustman, Mitchell and Steinmeier, 1994), so that even those portions of the trend to earlier retirement that are associated with changing Social Security and pension benefit formulas may reflect the effects of changing tastes, rather than the changing incentives in the opportunity set.

Cohort specific characteristics may be important determinants of retirement, and of retirement trends. Some potential candidates for cohort effects include the change associated with the increasing participation of women throughout their lifetimes, the changing structure of the division of labor in the household (more male hours, fewer female hours; see Juster and Stafford, 1991), and the changes in employer attitudes induced by the different histories and expectations about labor force commitment of the members of different cohorts. The literature does not, however, do a very good job of isolating cohort effects when explaining trends in retirement. Only time will tell whether these changes are adequately represented by differences among families in measurable characteristics, or whether behavior will differ among subsequent cohorts due to cohort specific effects.

Efforts are just beginning to expand the methodology available for examining the interdependence of family retirement decisions in a structural model, for incorporating measures reflecting job conditions or difficulty of work, and more generally for understanding the relation of financial measures, and of imperfections in capital markets, to retirement outcomes. ${ }^{8}$

The role of imperfect information, complex calculations and responses to uncertainty remain to be sorted out and satisfactorily modeled for inclusion in behavioral analyses of relevant policies. An extensive set of questions in the Health and Retirement Survey on expectations and attitudes about risky choices has been used to analyze relevant aspects of decision making in the context of the complex choices facing the potential retiree (Barsky, Kimball, Shapiro and Juster, 1993); but this

earlier retirement in Britain in the last two decades, where despite a decline in relative wages for the unskilled, their real wages continued to increase? If higher wages are responsible for the trend to earlier retirement, why did the trend only begin after the 1930s in the U.S.? And more generally, why aren't these wage effects picked up by structural retirement models?

${ }^{8}$ See the discussion in Hurd (1993) and Rust and Phalen (1993) for example. 
information has not been incorporated in a structural retirement model.

Many questions also remain about the relation of behavior to expectations. Formal models of the retirement decision assume that workers make decisions in each period to maximize utility over their remaining lifetimes. While some theoretical progress has been made in modeling such decisions in the presence of uncertainty, empirical work inevitably pretends that workers either know the value of future income streams associated with various choices or make rational expectations forecasts, and that they also know the "length of the planning horizon"-- i.e., how long the worker will live. The analysis of the relation of retirement expectations to incentives is encouraging (Hurd and McGarry, 1993b), but many questions remain unanswered. Previous research has suggested that there will be some whose expectations are unreasonable (Mitchell, 1988; Gustman and Steinmeier, 1989; Bernheim, 1988, 1989). In particular, there is a tail of the distribution with individuals who expect their benefits to be larger than is called for by their firm's pension plan, given their work and earnings history. More generally, we need to know expectations are formed, how they are revised, what differences there are in the formation of expectations and behavior for those who correctly report their constraints and for those who do not.

When the role of health status is measured in structural retirement models, it is measured by relatively direct questions about whether the individual suffers from health problems that impede work or other activities. ${ }^{9}$ Researchers are aware that reported health status may involve an exposte rationalization, where an individual reports he retired due to ill health, when that was not the motivating factor. This problem will be substantially remedied once panel data become available for estimating structural retirement models with the Health and Retirement Survey. The medical information is sufficiently detailed that it will be possible to isolate the effect of poor physical health from those of self rationalization in the health measures used.

'The studies with the best pension measures, those obtained directly from firm provided data, have no information on health status, e.g., Fields and Mitchell (1984) and Stock and Wise (1990a and b) and Lumsdaine, Stock and Wise (1990, 1992a and b). 


\section{B. Savings And Wealth Determination}

Savings and consumption analysis are major areas of economic research in both micro and macro economics. From the perspective of aging research, analyses pertaining to life cycle, precautionary and bequest motives are of particular interest. ${ }^{10}$ Sophisticated econometric models have been estimated with micro data on the basis of equations derived with each of these behavioral motivations in mind, and recent work has attempted to explain wealth and savings outcomes on the basis of more than one of these behavioral motivations. There also has been useful empirical research that imposes somewhat less structure, but focuses on major features of the data related to cohort and age effects. Also, there is a line of research that questions whether savers can make the sophisticated calculations called for by dynamic stochastic models of savings.

\section{Life Cycle Analysis}

A basic prediction of the simple life cycle model is that with a rising mortality hazard, once the sum of the time preference and the mortality hazard exceed the interest rate, consumption and wealth will fall with increasing age. A good deal of relevant evidence has been collected and is presented in Hurd, who argues that if panel data is used and it is corrected for the effects of mortality, profiles of bequeathable wealth do turn down at plausible ages and are consistent with the life cycle model. ${ }^{11}$

A number of anomalies have encouraged researchers to expand the model of savings beyond a perfect capital market--life cycle specification . Nevertheless, the forward looking consumer continues to characterize the central agent of many models of savings behavior.

\section{Precautionary Models Of Savings}

The individual faces a wide range of risks that might promote saving. If there are liquidity constraints or other factors creating incomplete markets for insurance, then a precautionary motive for

\footnotetext{
${ }^{10}$ Savers may also be motivated by needs to finance various expenditures such as their children's college education or the purchase of a home, or by other motivations.

${ }^{11}$ Hurd (1990a) also argues that consumption paths are consistent with the life cycle model.
} 


\section{Bequest Motive}

An alternative motivation for saving is to provide a bequest for one's heirs. The bequest motivation may be simple, to divide a fixed sum among one's heirs, or it may be complex, to leave a benefit in accordance with need, or involving a strategic arrangement in exchange for certain services from one's children. ${ }^{18}$ The fact that one leaves a bequest does not mean the bequest was intended, or that it was the amount that would have been delivered in a world with perfect foresight. In the absence of efficient annuity markets or insurance by families, individuals may be forced to under consume to avoid outliving their assets. ${ }^{19}$ Nor is it optimal for everyone to want to leave a bequest -e.g., children may be better off than their parents. Also, it is possible that consumption declines with age and bequests follow because for some, the capacity to consume declines with age. ${ }^{20}$

The evidence on the operation of a bequest motive is very mixed. The question is how important the bequest motive is relative to other motivations for savings, including the basic life cycle motivation. Consider the contradictory findings in a recent paper by Smith (1994). On the one hand, he finds that HRS respondents who believe that leaving an inheritance is very important have accumulated significantly more wealth $(\$ 85,000)$ than those who do not think that bequests are important. ${ }^{21}$ On the other hand, using panel data from the PSID, he finds, consistent with Hurd (1987), no linkage between savings and number of children ever born. ${ }^{22}$ Kotlikoff and Summers

heterogeneity in these measures within the population. For a study based on the new HRS data, see Barsky, Kimball, Shapiro and Juster (1993).

${ }^{18}$ E.g., see Becker (1991), Bernheim (1991) and Bernheim, Shleifer and Summers (1985).

${ }^{19}$ Kotlikoff and Spivak (1981), Davies (1981), Abel (1985).

${ }^{20}$ Borsch-Supan and Stahl (1991).

${ }^{21}$ Smith (1994) also finds that the bequest motive is more likely to be operating among those with higher incomes. He finds much smaller effects of a belief in a bequest motive when using median regressions than when using mean regressions.

${ }^{22}$ As a test of the importance of the bequest motive, Hurd (1987) examines the wealth path of families with and without children and concludes that the higher rate of decumulation of wealth by those with children is evidence against the importance of the bequest motive. 
(1981) suggest that the bequest motive accounts for the bulk of observed wealth, while Modigliani (1988) disagrees. ${ }^{23}$

Although the life cycle model considers the calculations of the individual or couple in isolation, research on bequest motives involves adopting intergenerational or family based models for analyzing consumption and savings. There is interest not only in the extent to which bequests are a motivation for savings, but also in what determines the amounts of bequests and the division of bequests among children and others. ${ }^{24}$

\section{Research Integrating These Motives}

Efforts at integrating these various explanations for savings do not yet involve estimating full structural models. One approach is to create simulation models on the basis of parameters obtained from original estimation as well as from other independent sources, and then to use the models to simulate the paths of asset accumulation. For example, Hubbard, Skinner and Zeldes (forthcoming) attempt to integrate a precautionary model of savings with a life cycle model, while including the effects of asset based means testing in social insurance programs. A related approach assumes higher rates of discounting governing the life cycle motivation, along with a precautionary motive in the context of a model with liquidity constraints and the need for buffer stocks against adverse events. ${ }^{25}$ The relative weight given in these models to life cycle retirement savings and precautionary savings varies. Nevertheless, the models do incorporate responses to risks such as those from earnings variation, health outcomes and uncertain length of life. These models do seem capable of reproducing important features of the data, and in particular, low levels of savings in early years, differences in savings among income groups, and savings and then dissaving through the life cycle.

\footnotetext{
${ }^{23}$ See, however, Kotlikoff's (1988) reply.

${ }^{24}$ Analysis of the effects of intergenerational linkages include Becker's analyses collected in Becker (1991), Barro (1974) and Bernheim (1991).

${ }^{25}$ See Carroll (1992), Carroll and Samwick (1994) and Samwick (1994).
} 
saving may be important. If there are high rates of time preference, then the precautionary motive may dominate savings behavior.

A basic fact puzzling researchers of savings is why such a large number of individuals reach retirement with little or no savings. This raises the question of whether the predominance of an alternative motivation for saving beside the life cycle model, and in particular precautionary saving, might account for the wide heterogeneity in observed outcomes. Others have been motivated by evidence that suggests to them that the young don't borrow, the old don't decumulate, and consumption growth is positive even when the interest rate is low or negative in a certain period. ${ }^{12}$ An analysis of precautionary motives must jointly explain how expectations are formed and the reaction to risk. In micro level studies there have been analyses of the properties of some of the major risks facing the individual, including pensions, earnings, length of life ill health and other factors. ${ }^{13}$ In the context of these analyses, it is also hoped that it will be possible to solve other puzzles, such as why consumption tracks income so closely ${ }^{14}$, suggesting the importance of liquidity constraints $^{15}$, and perhaps also to better understand how the saving motivation is affected by the availability of insurance. ${ }^{16}$

Researchers are investigating the best way to categorize and measure the effects of and the reactions to risk, distinguishing risk aversion from prudence, analyzing their properties and exploring the impact of these different features of preferences (Kimball, 1990, 1993). ${ }^{17}$

${ }^{12}$ Zeldes (1989).

${ }^{13}$ Skinner (1988), Carroll (1992), Guiso, Jappelli and Terlizzese (1992), Samwick (1993b, 1994) Hubbard, Skinner and Zeldes (1994b).

${ }^{14}$ Hall and Mishkin (1982), Carroll and Summers (1991).

${ }^{15}$ Zeldes (1989).

${ }^{16}$ Hubbard, Skinner and Zeldes (forthcoming).

${ }^{17}$ The Health and Retirement Survey is designed to permit direct measurement of individual's attitudes toward risk as well as their time preference and expectations regarding particular risks to the economy and to Social Security, among others, and to provide the opportunity to explore 


\section{Research That Imposes Only Limited Structure}

Some empirical analyses of asset composition rely on specifications that impose as little structure to the underlying model and error terms as possible, employing considerably less structure than is imposed by some formal empirical models of life cycle and precautionary savings. ${ }^{26}$ When not much structure is imposed, that limits, appropriately if the structure that would other be assumed is incorrect, the ability to predict the effects of policy changes. The alternative is to impose a specific functional form, a process that will reveal more of the key parameters required for policy analysis, on the assumption that the structure that is imposed is correct. Otherwise, the imposition of too much structure will create bias in the estimated coefficients, and will foster misleading policy analysis. Because of the continuing debate about the behavior underlying the savings decision, the extent to which these models should impose a particular structure continues to be a subject of disagreement. ${ }^{27}$

In some sense those who do not impose a great deal of structure on their empirical estimates have a different methodological perspective. Especially when investigating the effects of well defined policy changes, they are applying a quasi-experimental approach in which their major aim is to distinguish the effects of that policy, such as the adoption of rules permitting IRAs, or $401(\mathrm{k})$ plans. They are not, however, attempting to isolate the effects of the components of the policy. Often those who have a tight structural model in mind do not estimate the full structural model, but estimate a reduced form of one type or another. When that is the case, the parameter estimates obtained may be subject to a number of interpretations. Nevertheless they may provide useful information even if the full structural model is incorrectly specified.

\section{Research Arguing That Full Optimization Is Unlikely}

Thaler (1994) argues that a number of findings in the savings literature are inconsistent with

\footnotetext{
${ }^{26}$ See, for example, the models of Venti and Wise $(1986,1987,1990,1991)$ and Poterba, Venti and Wise (1993) for studies that separate cohort and age effects on savings.

${ }^{27}$ Venti and Wise (1992), Engen and Gale (1994).
} 
the predictions from leading models. ${ }^{28}$ This in turn leads him to suggest that the leading models are probably not accurately describing behavior. Among the reasons is the difficulty of the assumed optimization. It requires the solution to a dynamic programming problem that when specified to include the array of risks that are encountered requires a super computer to solve, is too hard even for as if behavior, especially because the behavior is not repeated but occurs only once in the lifetime. Moreover, because the problem is so complex, easy rules of thumb do not bring us close to the right answer. Bounded rationality and lack of self control leads him to suggest an approach to savings based on mental accounts, in which substitution among types of savings meant for different purposes is highly imperfect. Bernheim (1993a) expresses doubts that the population is sufficiently economically literate and has discussed the importance of providing adequate information through the Social Security system. There is not sufficient understanding of the limitations in our computational abilities to predict what the effects will be of providing potential retirees with increased information, as the new Social Security Administration initiative to inform individuals as to their entitlements will do.

\section{Continuing Controversy In The Savings Literature}

A major question in the savings area is how to reconcile the findings and models that have been developed with different behavioral motivations in mind. A number of the approaches to retirement savings summarized above are fundamentally inconsistent with each other. And in addition the relevant facts remain in dispute. ${ }^{29}$ When policy innovations arise, such as the availability of IRAs and $401 \mathrm{k}$ 's, either new savings is generated or it is not. ${ }^{30}$ Either those with pension or housing

\footnotetext{
${ }^{28}$ See also Deaton (1991) and Zeldes (1989).
}

${ }^{29}$ Hamermesh (1984) argues that asset decumulation is too rapid to sustain consumption after retirement. On the other hand, it has frequently been argued that decumulation is too slow for a life cycle motivations and that bequests will result. (See Kotlikoff and Summers, 1981).

${ }^{30}$ For discussion of the continuing debate on this topic, see Venti and Wise (1987), Poterba, Venti and Wise (1993, 1994), Gale and Scholz (1994), Engen, Gale and Scholz (1993). For a critique of the latter study, see Bernheim (1994). 
wealth reduce their holdings of financial assets proportionately, or they do not. ${ }^{31}$ Without resolving these questions, which requires resolving ongoing controversies in the literature, we are in no position to judge the effects of a number of important policies that will affect savings.

The difficulties that modelers have faced in explaining these facts. are widely appreciated. Some argue that it is a matter of integrating the various motivations and constraints into a single framework. ${ }^{32}$ Some suggest that many of the outcome differences may be due to unmeasurable differences in taste, and that selection issues will be difficult to unravel. ${ }^{33}$ Others suggest that in analyzing savings behavior, we are at the limits of the usefulness of a model that assumes full information and complete and rational decision making. ${ }^{34}$ The question of the importance of each of these motivations for savings has yet to be resolved.

With regard to the analysis of savings, a fundamental task is to reconcile the competing explanations for the observed behavior. The puzzling differences in savings outcomes within the population, the failure to explain low savings rates and the counterintuitive findings on the substitution among different types of savings vehicles provide an opportunity to reconcile these results. A basic question in the savings literature is whether it will be possible to explain observed behavior with a significantly modified life cycle model that integrates some of the other leading explanations for savings behavior. The weights given to these various motivations are unclear and at times appear inconsistent. It is possible that a different mix of theories may be required at different points in the income distribution to explain the variety of behaviors observed for those with different incomes.

\footnotetext{
${ }^{31}$ Those with a pension save less than those without a pension (Smith, 1994), but there is a question about the rates at which these assets are substituted. See, for example, Bernheim and Scholz (1993) and Samwick (1994) on the relation between pension holding and nonpension wealth. See Hoynes and McFadden (1994) for evidence on the nonhousing wealth of those who do and do not own houses.

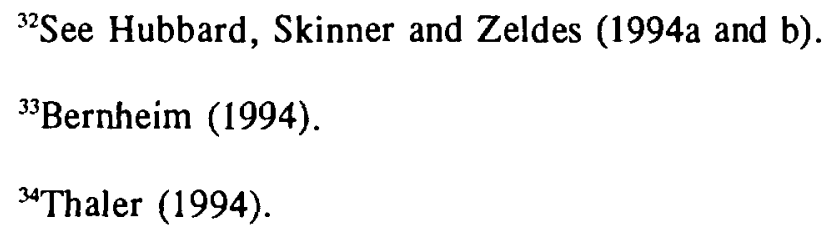


Alternatively, it may be necessary to pay much greater attention to the difficulties of making life cycle calculations, incorporating rules of thumb, and importing ad hoc or nonconventional explanations for imperfect substitutability among various types of savings instruments, the very high apparent rate of time preference among younger workers, and the wide heterogeneity in savings and high frequency of zero savers.

\section{Pensions And Social Security}

\section{At The Level Of The Individual}

At the level of the individual's decision, Social Security and pension income are the result of joint choices determining labor supply and benefit acceptance. The provisions of Social Security and pensions are taken as exogenous to the choices the individual will make. Pension benefit coverage, pension formulas and earnings histories of each individual determine potential pension incomes in retirement, conditional on the choice of retirement date and on the timing of pension and Social Security acceptance. ${ }^{35}$

It is straight forward to apply retirement models to explain the effects of changes in Social Security and pension policies on retirement outcomes, and on incomes from pensions and Social Security in retirement. ${ }^{36}$ However, there are some questions that arise from findings that suggest both

${ }^{35}$ See Burkhauser (1979) and Rust and Phalen (1993) among others.

${ }^{36}$ One set of results suggests that although Social Security benefit changes adopted in 1983 will reduce retirement incomes by about 14 percent by the time they are fully phased in, half of the reduction will be offset by induced increases in earnings as retirement is postponed in response to the change in incentives (Gustman and Steinmeier, 1985a). Another set of results suggests that accelerating the 1983 Social Security reforms to eliminate penalties from continuing work after reaching Social Security normal retirement age, or equivalently abolishing the retirement earnings test, will have only a small effect on retirement in the affected cohorts (Gustman and Steinmeier, 1991). Simulations with models fit to payroll data from selected firms (Stock and Wise, 1990a and b; Lumsdaine and Wise, 1990; Wise and Woodbury, 1994) suggest that retirement incentives from Social Security are much weaker than are incentives from pensions. Other recent work focuses on the proper modeling of Social Security effects on retirement (Reimers and Honig, 1993a and b; Rust and Phalen, 1993). These studies suggest that simple, mechanical models of a response to the benefit formula and earnings test are unsatisfactory, and that liquidity constraints, knowledge of the earnings test, and the nonwage characteristics of jobs (Hurd and McGarry, 1993a and Gustman, Mitchell and Steinmeier, 1994) are important. 
that individuals may not fully understand the rules governing Social Security, and that they may be liquidity constrained, a possibility that has been recognized but that is not incorporated in most dynamic life cycle models of labor supply. ${ }^{37}$

In analyzing the incentives from pension plans, findings suggest that if the pension formula is not actuarially fair, this may have a significant effect on the ultimate level of pension wealth. Changes in pensions and Social Security may induce further changes in savings behavior. But to predict the second order effects of these changes will require a greater understanding of savings behavior than we now have.

\section{Pension Plan Determination At The Level of The Firm}

A basic building block in the conventional model explaining the demand for private pensions is the tax favored status of the pension. Even the simplest models of why firms adopt pensions predict that workers will like to substitute the tax favored savings available under pension plans for private savings and that it is in the interest of firms to accommodate this demand. ${ }^{38}$ Early studies of the reaction between pensions and savings suggested greater savings by those who were covered by

${ }^{37}$ The suggestion that workers may not fully understand the Social Security rules comes from a finding of a spike in the participation rate at the disregard amount of the Social Security earnings test (Burtless and Moffitt, 1984). The rules allow any benefit that is lost to the earnings test by someone between the ages of 62 and 65 to be recovered in future years on a roughly actuarially fair basis, so that the spike at the disregard amount does not make sense for those under 65 if they understood the rules. Analogously, incentives from Social Security should not create a spike in the retirement hazard at age 62 in that any loss to the earnings test can be recovered in future years (Hurd, 1990a).

Nevertheless, in some studies there is a suggestion of a spike in the retirement hazard at age 62 which seems to be associated with Social Security. Specifically, while findings in Gustman and Steinmeier (1986a) suggest that spikes in retirement hazards can be attributed completely to actuarial incentives of pensions, Social Security and mandatory retirement, without considering any effects of liquidity constraints, Hurd (1990a), using data from Kotlikoff and Wise $(1985,1987)$, finds a spike in the retirement hazard at age 62 for workers with a pension plan that does not generate any retirement incentive at age 62. This leads Hurd to infer that liquidity effects associated with Social Security are responsible, a finding confirmed in subsequent analysis by Wise and his colleagues. Nalebuff and Zeckhauser (1985) explain why liquidity effects may also arise from pension plans that are designed for a heterogeneous work force.

${ }^{38}$ E.g., see Woodbury (1983) and Woodbury and Huang (1991). 
pensions. ${ }^{39}$ A survey by Munnell and Yohn (1992) of studies conducted in the 1970's and 1980's suggests that there is substitution but that it is imperfect. More recent studies using actual rather than expected pension amounts or coverage suggest that the substitution is weak or nonexistent.

Controlling for lifetime income, those with higher employer provided pension assets do not exhibit lower personal retirement saving. ${ }^{40}$

There is a substantial literature arguing that the firm has other motivations for pensions. Given its goal of maximizing profits subject to constraints from the production technology and factor supply curves, and operating within the implicit contract, the firm is hypothesized to choose parameters of pension plans to allocate compensation optimally among wages, pensions and other fringes, to influence employment, worker productivity and other dimensions of costs.

Undoubtedly the tax favored status of pensions contributed importantly to their spread in the post World War II period (Ippolito, 1986). It is therefore quite surprising that the evidence that those with pensions reduce their savings in other forms is ambiguous. There are other questions about the behavioral mechanisms driving the determination of the coverage, terms and amounts of pension savings, choice of plan types, explanations for pension backloading, and relationships of pensions to wages, turnover and other dimensions of labor quality. Many of the human resource motivations which are said to underlie or buttress the demand for pensions are not consistent with the data.

Consider the questions that may be raised about the elaborate models of implicit contracts in which pensions are used as a tool of human resource policy to screen workers on the basis of unmeasured ability, and to prevent shirking. Elements of these models that are not consistent with the data include the presumption that pensions provide a strong incentive against mobility in the years following hire and initial training (the incentive is really quite weak), that mobility is lower from

\footnotetext{
${ }^{39}$ Cagan (1965), Katona (1965).
}

${ }^{+0}$ See Venti and Wise (1993) for a discussion and evidence of imperfect substitution between personal retirement savings and a number of other savings instruments. Venti and Wise include assets in $401(\mathrm{k})$ plans under the heading of personal targeted retirement assets, as opposed to employer provided pension assets. See also the evidence in Samwick (1994). 
pension covered jobs because of pension backloading (mobility is lower from pension covered jobs whether the pension is defined benefit and backloaded or defined contribution and not significantly backloaded), and that workers are inhibited from shirking because they are afraid they will lose their backloaded benefits if fired from a job offering a DB plan (workers have.only a modest understanding, if that, of the incentives in their pension plans). ${ }^{41}$

Anomalies appear in studies with overidentifying restrictions. In turnover models we find that constraints requiring identical coefficients for wage and pension terms are violated, and that the estimated coefficients differ by orders of magnitude. Within models of compensating wage differentials for pensions, we find that findings are not robust. And it is apparent from examining empirical work that identification has sometimes been forced, e.g., by instrumenting on what are clearly endogenous variables -- using some pension characteristics as instruments in a model that is designed to explain pension and wage outcomes. ${ }^{42}$

The conventional models also generate other predictions that do not accord with the data, raising concern for our ability to predict how private pensions will respond to changes in pension policies, tax policies, or to changes in the Social Security system.

Among the empirical regularities that pension studies attempt to explain is the basic result that compensation accrual and productivity do not correspond in each year of attachment, and the existence of other unique labor market institutions, such as mandatory retirement provisions which were common place before they were banished by law. Researchers have also tried to understand why defined benefit pensions are backloaded (that is accrue more in later than in earlier years), why union pensions are underfunded relative to nonunion pensions, why workers are less likely to leave pension covered jobs than jobs without pensions, why firms grant post retirement benefit increases

\footnotetext{
${ }^{41}$ For discussions of these and related predictions from conventional models of pensions that attribute the attraction of firms to pensions to their human resource properties, see Gustman and Steinmeier (1989), Gustman and Mitchell (1992), Gustman, Mitchell and Steinmeier (1994), and Gustman and Steinmeier (forthcoming).

${ }^{42}$ For details see Gustman, Mitchell and Steinmeier (1994).
} 
and other puzzles. ${ }^{43}$ They also have attempted to generate predictions from models of long term worker attachment and to test those predictions. ${ }^{44}$ Other efforts have described the differences in pension outcomes among demographic, firm and industry groups, by unionization, and other factors. Among the major differences in pension outcomes are differences in plan types, that is whether the plan is defined benefit or defined contribution. ${ }^{45}$ Still other studies have focused on documenting the trends in pension outcomes and explaining the reasons for these trends. ${ }^{46}$ After rising during the 1960 s and 1970 s, pension coverage ceased to grow in the middle 1980s. Now there is evidence that the upward trend in coverage, especially for DC plans, may have resumed in just the last year or two (EBRI, 1993). ${ }^{47}$

Despite all of the efforts to explain the regularities in pension related outcomes, most testing looks for partial relationships in the context of multivariate single equation models. There has been no structural analysis on the firm side analogous to that available for analyzing behavior and policies from the perspective of the individual. This greatly limits our ability to use the available empirical work on pensions to predict the effects of pension regulations and pension policies on income and others.

${ }^{43}$ See, for example, Lazear $(1979,1983)$ and Ippolito (1983, 1985a and b, 1986 and 1987) among

${ }^{44}$ See, for example, Hutchens $(1986,1987)$ and Stern and Todd (1993).

${ }^{45}$ Studies of pension outcomes discuss the effects of certain plan differences, e.g., Green (1985) and Bodie (1990) analyze the differential risk of defined benefit and defined contribution plans. Most of the empirical studies of the choices of pension outcomes are descriptive, relating pension outcomes to demographic and employment characteristics.

${ }^{46}$ Relevant studies are reviewed in Gustman, Mitchell and Steinmeier (1994).

${ }^{47}$ Recent articles examining trends in pension coverage include Parsons (1991 and 1993), Bloom and Freeman (1992), Turner and Beller (1992) and Even and Macpherson (1993). Other studies have tried to describe and explain trends in plan type (Clark and McDermed, 1990; Gustman and Steinmeier, 1992; Ippolito, forthcoming; Kruse, forthcoming); and to understand the forces shaping the trends in provision of pensions (Mitchell and Luzadis, 1988; Luzadis and Mitchell, 1991; Mitchell, 1992). 
wealth outcomes. A basic reason is that the data are not available at the level of the firm. ${ }^{48}$ And with all of the remaining questions about the importance of the competing motivations determining pension design, it is premature to impose a comprehensive model.

In sum, the pension literature is very far from generating empirical estimates of a reliable behavioral model. We certainly have no model with sufficient structure that it can be used to predict the effects of pension policies on the basic pension outcomes, including pension amounts, plan characteristics, insurance features or other outcomes that will be useful in understanding how pension policies will affect retirement incomes and wealth. Nor can we predict the effects of these policies on wages.

\section{Research On Family Structures And Transfers}

There is some research linking earnings, wealth and savings behavior to family structure. Earnings equations consistently find that earnings are higher among married individuals. With regard to savings and wealth, Smith (1994), for example, finds higher assets and savings of married couples than unmarried individuals, even after standardizing for differences in incomes and using longitudinal data to distinguish the effects of selectivity of marital state, in which lower income families are more likely to dissolve. Thus the need for help in old age is likely to be affected by the history of marital status. And of course, the availability of help in old age is going to depend on whether unmarried individuals were ever married, and whether they had children.

Living arrangements in old age are different from those at younger ages, reflecting not only the course of the life cycle as children leave home, but also the effects of mortality. Women are more likely to survive than men, so older households are more likely to include a single woman than a single man. When the survivor is a woman, however, the household is likely to be poorera9.

\footnotetext{
${ }^{48}$ For a discussion of the data that are available, the shortcomings in the data, and what would be required to support policy analysis, see Gustman and Mitchell (1992).

${ }^{49}$ See Hurd and Wise (1989) and Burkhauser, Holden and Feaster (1988) for studies addressing the economic status of widows.
} 
Nevertheless, increases in real income over time have resulted in a halving of the fraction of older women living with relatives..$^{\text {so }}$

Work on family structure and transfers spans analyses of the decisions of families to transfer assets among members, from the bequest motives through transfers from children or siblings to their parents. Moreover, decisions for multiple generations to live together affect decisions about the need to purchase (and save or insure for) different types of care outside the home, such as to enter a nursing home. The basic structure of behavioral models ranges from Becker's seminal work, including matching models that underlie the decision to form and leave a family and intergenerational models of transfers that have been used to explain bequests and care giving to parents ${ }^{51}$, to econometric models of household dissolution (Borsch-Supan, 1989, Borsch-Supan, 1990, and BorschSupan, McFadden and Schnabel, 1993), to analysis of housing demand by the elderly (Feinstein and McFadden, 1988), to models of demand for nursing homes (Garber and MacCurdy, 1990).

Integrated structural models have not yet been estimated. ${ }^{52}$ The Health and Retirement Survey and the Ahead Survey are going to provide excellent data for testing the integrated models of family relationships that are currently being refined. ${ }^{53}$ These data are going to tightly constrain explanations, forcing researchers to integrate explanations based on intergenerational insurance, altruism and bargaining models. But they do have a considerable way to go before we have structural models of the type needed to simulate the effects of changes in tax policies, income and wealth testing of benefits, or health benefit policies, on the full array of outcomes that may be generated, including not only living arrangements, but an understanding of the feedback on the income and wealth of the older family unit.

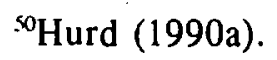

${ }^{51}$ Becker's contribution is collected in the 1991 version of his Treatise on The Family.

${ }^{52}$ For reduced form analyses using the HRS and PSID, see McGarry and Schoeni (1994).

${ }^{53}$ For summaries and recent research, see Soldo and Hill (1993) .
} 
We are only beginning to explore the questions related to family structure and transfers, and their linkage to labor supply, savings and pension determination. Living arrangements are a first outcome that will be investigated with more sophisticated models. We have mentioned the rising interest in models of joint labor supply behavior. Structurally this is going to involve the introduction of bargaining models. Bargaining models are also a natural for trying to understand savings behavior. But to learn a lot more about the relation of family prospects to these dimensions of behavior is going to require specification of a credible mechanism and careful measurement of the threat price.

Extensions of these models to an intergenerational setting will be required to resolve some of the continuing controversy about the motivations for bequests. We have yet to determine the motivation for dividing bequests, and whether bequests are treated as a form of insurance. Analogous issues also arise from the perspective of the transfer of time and money from children to parents, including the issue of how responsibilities get divided among children and why.

It appears that intergenerational linkages may be important in explaining the differences among countries in their savings behavior. ${ }^{54}$ Where appropriate credit markets are not well developed, generations are more likely to be living together, making intergenerational transfers more of an everyday occurrence. There are models of the family as annuity market. ${ }^{5 s}$ These behavioral models and changes in behavior with the rise of Social Security suggest that intergenerational linkages are no longer as important as they once were, but nevertheless suggest that family linkages should be explicitly considered when analyzing the determination of labor market and savings behavior.

\section{E. Research On Housing}

Housing wealth peaks for older households between $55^{\circ}$ and 70 . About four out of five older households own a home. At least until they reach their early seventies, home owners do not draw

\footnotetext{
${ }^{54}$ See Poterba (forthcoming).

${ }^{55}$ Kotlikoff and Spivak (1981).
} 
down on their housing wealth. Although it may be argued that stickiness in housing wealth reflects the fixed costs of location, older home owners do not adjust housing equity even when they move (Venti and Wise, 1989). Among those over 70, there is some evidence that older individuals do draw down on their housing wealth, but not at a rate that would be suggested by life cycle consumption (Sheiner and Weil, 1992). This suggests that housing wealth may be useful for a bequest motive, or that it is an asset that is held to meet precautionary motives in old age. In the latter case we may find that the median older person is not downsizing, but a person in the bottom of the income distribution who is in a bad state is. Still, it does not appear that housing wealth is a close substitute for holding other forms wealth, which presumably are held to meet similar goals. ${ }^{56}$ Moreover, while people do spend a portion of windfall gains to their housing assets, they incorporate changes in housing wealth in their other asset holding only when housing assets decline in value (Engelhardt, 1994). Nor are the elderly enthusiastic about accepting reverse mortgages. In fact, Venti and Wise (1990) calculate that drawing down housing wealth through reverse mortgages would supplement the incomes of older families by only ten percent. This suggests that housing equity could not substantially supplement the incomes of older Americans.

Large transaction costs make it difficult to isolate the relation of housing wealth to models of savings discussed above. Hurd (1990a) cites evidence on changes in housing wealth among those who turnover that he feels is consistent with the life cycle model. Nevertheless, he prefers testing the life cycle model by using wealth data that excludes housing wealth. All of these findings leave us with a collection of facts, but raise a number of questions about how housing demand fits in with other dimensions of savings and wealth behavior.

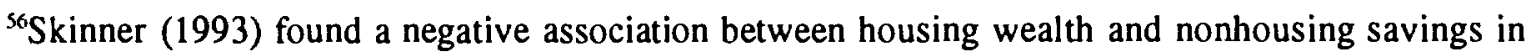
the PSID, measuring housing values by the individual's self report of the housing value in two different periods. Hoynes and McFadden (1994) use data on housing prices in metropolitan areas and find either a very small positive association between changes in housing prices and the savings rate, or a larger one, depending on specification. When Skinner reestimates the results in Hoynes and McFadden using median regression, reducing the weight on outliers, he finds a significant but modest effect of housing wealth on savings. 


\section{Reconciling Research On Labor Supply, Savings And Pensions}

At least as disturbing as the formidable array of questions about our leading models within each of the separate areas of inquiry, labor supply, savings and pension determination, is the inconsistency among these three related areas of inquiry. Research in each area of behavior ignores findings from the other areas of behavior. For example, many models of savings assume that retirement is fixed, so that insurance against unexpected earnings risk afforded by a flexible retirement date is ignored. Even when related behavior is not ignored, it is oversimplified. For example, savings in structural retirement models is either assumed to be motivated by life cycle savings, with savings choices made in the context of a perfectly operating capital market, or in a world where income and consumption are assumed to be identical. ${ }^{57}$

Mechanically, with three major behavioral models, there are six linkages in each direction that we would like to understand. We would like to understand the linkages from labor supply to savings behavior and pension plan determination, from savings behavior to labor supply and pension plan determination, and from pension plan determination to labor supply and savings.

We are not talking here about effects that have a secondary impact on the mode of behavior under examination. Thus, for example, consider the consequence when most structural retirement models greatly oversimplify the motivations for savings and assume either that earnings are being reallocated to finance consumption in accordance with a simple life cycle motivation in a perfectly operating capital market; ${ }^{77}$ or that lending and borrowing is not at all possible. ${ }^{78}$ As is well known, if those approaching retirement with no liquid assets are over-annuitized, they may time their retirement

\footnotetext{
${ }^{57}$ In either case such phenomena as the bunching of retirees at the Social Security earnings test maximum is difficult to explain. See Burtless and Moffitt (1984).

${ }^{n}$ Rust $(1989,1990)$ developed an influential model of the joint determination of savings and retirement, but that model has not been estimated. Otherwise, all of the structural models mentioned above are estimated using procedures that ignore information about savings behavior.

${ }^{78}$ E.g., see Rust and Phalen (1993).
} 
decision to regulate not only the amount of leisure, but also the path of consumption over time. ${ }^{79}$ If that is the case, then parameters estimated in models that assume perfectly operating capital markets may be misleading, perhaps significantly so. On the other hand, we know that saving behavior is heterogeneous. Certainly those that approach the retirement date with some liquid assets are less likely to be over-annuitized, and thus should not be influenced by the age 62 early retirement provisions of Social Security. Thus the assumption that all retirees in a certain class are liquidity constrained is also likely to lead to bias, perhaps significantly so.

Moreover, if liquidity constraints play an important role, as they do in some models of precautionary savings, then effects of policy changes that are benign when viewed from the perspective of standard retirement models, may have significant behavioral consequences. For example, according to most structural retirement work, moving the early retirement age under Social Security from age 62 to 65 should have little effect, so long as the present values are not disturbed. Under the current system, benefits adjustments for work after 62 are actuarially fair. Even if liquidity constraints would normally inhibit borrowing, there should be little effect of having to wait for Social Security benefits that late in the life cycle, since all life cycle savings should have been completed. Yet if significant numbers enter retirement lacking financial wealth, as appears to be the case, then as suggested by Rust and Phalen's work, moving the retirement age from 62 to 65 will indeed have the effect of raising the retirement age. Consequently, the effects of certain policies will be misunderstood in retirement models that do not incorporate the effects of savings behavior.

The difficulties in understanding savings behavior thus have implications not only for the determination of income from nonpension savings, but also for understanding retirement behavior, and thus for the path of income from earnings.

Consider next the implications of retirement research for the models of savings behavior.

\footnotetext{
${ }^{79}$ Nalebuff and Zeckhauser (1985), Hurd (1990a), Rust and Phalen (1993) and others note that in the absence of assets, liquidity constrained individuals will retire at 62 to obtain access to their Social Security benefits.
} 
From the perspective of the precautionary model of savings, certain motivations cannot be insured by changing labor supply behavior. But certainly some variations in wages can be insured against by postponing retirement. Indeed, over the life cycle, it may also be possible to adjust to certain shocks by changing the allocation of work within the family, or changing hours of work once the shock is resolved. Nevertheless, most savings models, even models of precautionary demand, take labor supply and retirement behavior as fixed. ${ }^{80}$ Assuming fixed retirement dates can have adverse consequences for savings research for other reasons. As pointed out early in the savings literature, those who have preferences that favor early retirement, or who are working for firms that encourage early retirement, may be observed to have higher savings rates. To the extent that these considerations are ignored, it will appear that they will have higher life cycle savings. In fact, the amount of life cycle savings may be lower for early retirees once their shorter period of attachment to the labor force is taken into account.

Pension research also has implications both for retirement research and for savings research. With regard to retirement research, the issue of the possible endogeneity of pensions may be raised. Pensions are determined by the firm with the preferences of covered workers in mind. This raises the question of whether the effects of pension incentives on retirement are exaggerated. It is possible to argue that the sharp changes in pensions over the past two decades could not have been foreseen by those approaching retirement age, so that they did not select their jobs on the basis of a taste for early retirement. ${ }^{81}$ Nevertheless, it still is in the firm's interest to shape the pension to accord with worker preferences. Thus a relationship between early retirement provisions in pension plans and retirement outcomes may to some extent reflect the firm's efforts to accord with their own workers' tastes,

\footnotetext{
${ }^{80}$ See, however, Samwick (1994).
}

${ }^{81}$ The normal retirement age for pension covered workers in the Retirement History Study averaged 64.2. The early retirement age averaged 61. According to 1989 SCF data, the normal retirement age averaged 61.7 and the early retirement age averaged 54.3 (Anderson, Gustman and Steinmeier, 1994). For data on the changes in early retirement provisions of pension plans over the past two decades, see Ippolito (1990) and Mitchell (1992). 
leading to an overstatement of the effect of pension incentives on retirement.

With regard to savings research, one cannot help but be puzzled by recent findings that those with pensions do not reduce their saving correspondingly. If we correctly hold constant factors associated with differences in tastes and standardize for incomes, it is hard to conceive of a model in which pensions should not substitute for financial savings, or at least for that portion of financial savings meant to finance retirement. Not only are pensions a tax favored form of savings, but the defined benefit plans carry one of the few opportunities to purchase an annuity with a price that is not increased substantially by the effects of adverse selection. Moreover, the penalties are small enough that many forms of pension savings can meet the demands for other types of savings, such as saving to pay for the children's college educations. Somewhere in the process, one suspects that preferences are being changed as firms and unions provide information about the importance of retirement savings or for other reasons. This information must in turn be affecting the demand for financial savings, creating an unmeasured linkage between pensions and financial savings.

We have already seen that savings research also has implications for pension research. The recent evidence that substitution between pensions and savings is weak or nonexistent is not consistent with the standard tax based explanation for pensions..$^{82}$ It is not that we doubt that the favorable tax treatment of pensions underlies much of the growth of pensions (Ippolito, 1986). It does appear, however, any effort to fit a model of pension demand must go beyond the mechanical substitution of pension for nonpension savings and provide an explanation for the empirical findings in available studies of pensions.

There are no simple fixes for these problems. But they do provide an important agenda for future research.

\footnotetext{
${ }^{82}$ Venti and Wise (1993) find no evidence of any offset at all between pension wealth and personal financial assets, with the coefficient on the relationship being positive but insignificant. See also Bernheim and Scholz (1993), who relate savings to a qualitative indicator of pension coverage, and find an indication of some substitution for those with college degrees.
} 
V. What Kind Of Models And Data Are Needed To Do An Adequate Job Of Understanding The Determination Of The Incomes and Wealth of Older Americans?

In each of these separate areas of behavior, the direction that research is taking is appropriate. The basic outlines of dynamic retirement models are established. The models of savings behavior require further integration of competing motivations into a single framework. Models of pensions will require a further understanding of the motivation of the demand for pensions by workers as well as the behavior underlying human resource policies of the firm and their importance in shaping pensions. The question is how long it will take and how much progress will be required before we are in good enough shape to analyze the effects of the detailed policies specified in the next section.

The question facing those who would wish to use structural modeling as a basis for policy analysis in the more immediate future is, do we know enough about behavior to be comfortable imposing a model with sufficient structure to allow analysis of the effects of detailed changes in policy? A basic test of any model, and of the structure it imposes, is whether the model can explain major features of the data. If the structure is wrong in some fundamental way, we should be able to find important characteristics of the data that the model cannot explain. In the case of models of savings, retirement and pensions that would be used for policy analysis, there is a great deal of data that could and should be brought to bear before policy analysis based on the model is taken seriously.

Approaches that create complex models by borrowing parameters from various sources face significant problems. Presumably to avoid the kind of specification error that occurs when parameters are estimated in the context of a partially specified set of behavioral equations, we should eventually expect structural equations of more complex models to be estimated directly from data. Only in the area of retirement modeling have we come close to meeting this criterion.

There may be classes of models that achieve a balance, on the one hand providing sufficient structure to analyze effects of complex policies, while resisting any temptation to over-parameterize, creating potential errors of the type we have been discussing. To the extent that the investigator has sufficiently good intuition, the policy analysis that emerges may not be badly biased by the failure to 
fully specify all dimensions of behavior. It is difficult to determine exactly when this goal has been achieved, but there is sufficient data to put any model through its paces.

To the extent that the three dimensions of behavior we have focused most strongly on, labor force participation, savings and pensions, are separable, this careful balancing act is likely to be most successful. Otherwise, structural models incorporating the three types of behavior will be required to analyze the array of policies affecting incentives to retire, to save and to form pensions with different characteristics. Even if behavior in each of the three areas were separable, the task ahead is formidable. Our descriptions of the motivations governing retirement, savings and pensions must accurately depict the relevant behaviors, and as the discussion has indicated, a great deal of work is required before we reach that goal.

If retirement, savings and pension plan determination are not separable modes of behavior, then before we can generate a set of equations useful for analyzing the types of structural changes that major policy innovations create, it will be necessary to make progress on all three fronts. Available models fail to consider the relation between the behavior being analyzed and the other leading modes of behavior that have been noted here. This leaves open the possibility that the parameters we have are biased and will provide misleading predictions about the likely effects of major policy initiatives.

Thus in deciding on priorities for future research, we must answer questions such as the following: If the motivation for savings takes us well beyond the simple life cycle model, what are the implications for parameter estimates obtained in most of our life cycle labor supply models? If pensions are designed to meet the preferences of the work force, how serious is endogeneity of the pension incentives for our measurement of worker preferences? If the motivation for pensions is more complicated than the simple substitution of a tax favored form of savings for one that is not (and many human resource explanations for pension characteristics are inconsistent with the data), then how can we integrate the findings from savings and pension theory to better understand what is driving pension coverage and the choice and structure of pension plans? 
These efforts will be aided by the availability of data from the HRS and AHEAD surveys. The HRS was designed with dynamic, structural retirement models in mind, and provides the depth of information that will help us to improve our understanding of retirement behavior at the level of the individual. ${ }^{83}$ HRS and AHEAD were designed to provide the basic information needed to model retirement and savings behavior. Special efforts were made to reduce measurement error. Where possible, data have been matched from administrative records and from employer documents. For each individual we will have a record of Social Security earnings history and thus an objective record of employment that is not subject to recall bias. Incentives from pensions will be measured from pension data provided by the employer. As we have described before, innovations are being employed to reduce bias in measuring wealth. Moreover, there will be unique data for measuring the experiences of those with disabilities and of health problems in general, and for measuring the financial and nonfinancial support provided by family structures. Once the panel data are in, we will have two related sources of data that are capable of supporting the next generation of behavioral research. Having the data in these surveys is not sufficient to overcome the serious difficulties we face in isolating the true model, but these data will be a significant help.

What we do not have is comparable data for improving our understanding of the behavior of the firm that determines pensions and their characteristics. There are some efforts underway at the Bureau of Labor Statistics to make available establishment data collected in the Employee Benefit Survey and the Employment Cost Index, but we are a long way from meeting the requirements for release of a data set that can support the types of behavioral models that are required for policy analysis.

\footnotetext{
${ }^{83}$ These data sets and their potential use in research on retirement, savings, health, family linkages and related issues are described in detail in a forthcoming issue of the Journal of Human Resources.
} 


\section{Selected Policies Affecting Retirement Incomes And Wealth}

To conclude the paper, we return to the box labeled D in Figure 1, and outline briefly an array of policies changes that have the potential of affecting significantly the incomes and wealth of older Americans. These policies, if adopted, would change the incentives for retirement, savings and pensions.

A wide variety of Social Security reforms have been recommended in the past, and may be considered again in the future. One suggestion pertains to accelerating the reforms already scheduled under the 1983 Social Security Amendments. Thus instead of proceeding according to the schedule under current law, under an accelerated schedule, the normal retirement age would be raised to 67 and the delayed retirement credit increased to 8 percent immediately. The effect would be to decrease Social Security benefits for the transition generation as they will be for all cohorts that face an age 67 retirement age, and to increase the incentive to delay retirement age. A related suggestion is to abolish immediately the retirement earnings test. ${ }^{84}$ After the recent increase in the portion of Social Security benefits subject to income tax, there have been suggestions to means test Social Security benefits. It is also continually suggested that changes be made in the treatment of spouse benefits under Social Security.

A more sweeping recommendation that continues to surface would allow some sort of privatization of the Social Security system. One possibility is to allow those who save in a tax favored vehicle to opt out of the system, as is now possible in Britain. Here the likely effects would incorporate fundamental reactions based on dimensions of behavior affecting labor supply, savings and pensions. For example, such a program would probably encourage firms and workers to cash out defined benefit pensions to provide benefits in a form that would allow covered workers who found it

\footnotetext{
${ }^{84}$ These suggestions were made by Dorcas Hardy, the former head of the Social Security Administration, and continue to be made by others. For an analysis, see Gustman and Steinmeier (1991).
} 
to their advantage to opt out of the Social Security system to in fact do so. ${ }^{85}$

We have been in the throes of a major health care reform debate. The role of retiree health insurance has received a good deal of attention in the course of that debate. We will not guess the outcome of health care reform, but changes that might be considered either in the context of the current round of reform, or some time in the future, include reducing the age of eligibility for Medicare, or otherwise breaking the linkage between work and health insurance. ${ }^{86}$ With further pressure on the Medicare system, proposals are also surfacing for means testing Medicare benefits.

Potential pension reforms continue to be formulated with at least five goals in mind: to increase coverage, to reduce revenue losses through tax deductibility, to protect the implicit pension contract, to increase the incentive to postpone retirement, and to level the distribution of benefits among high and low income employees. ${ }^{87}$ Potential changes in policies could change the tax treatment of pensions, mandate the availability of pensions, alter a variety of eligibility and vesting rules, further change treatment of spouses under pensions, further change funding rules including minimum and maximum funding levels, change treatment of retiree health benefits, change acceptable actuarial assumptions and procedures, alter discrimination rules, including further regulation of matching provisions under $401(\mathrm{k}) \mathrm{s}$, change rules governing Social Security offsets, change the rules governing pensions of high paid employees, regulate the backloading of pensions, require payments to terminated vested employees to be based on projected earnings or some related mechanism rather than using the last few years of nominal earnings in calculating benefits, adjust rules affecting the returns

\footnotetext{
${ }^{85}$ We have not emphasized the disability system, but clearly changes in disability rules will affect incentives to save for precautionary reasons. Moreover, disability provisions may interact with early retirement provisions of pension programs affecting retirement incentives. Because the roll of the disability system has grown rapidly in recent years and the finances of that system have deteriorated, there have been a number of suggestions for change. Such changes might, for example, include tightening eligibility requirements, reducing benefits and limiting the duration of benefits.

${ }^{86}$ For conflicting analyses of the effects of retiree health insurance on retirement, see Gustman and Steinmeier (1994) and Karoly and Rogowski (1994).

${ }^{87}$ Pension discrimination rules attempt to equalize benefits within firms. Special pension regulations pertaining to high income employees limit the absolute size of benefits.
} 
to invested pension assets by further regulating these investments or mandating certain types of investment, change rules governing asset investments for defined contribution plans, regulate or mandate post retirement benefit increases, regulate rollovers from pension plans, and introduce an array of policies that would affect the terms of PBGC insurance. ${ }^{88}$

One of the more-controversial proposals that would reduce taxes on the income from savings is to resurrect the Individual Retirement Account in its initial form, as favored in the past by Treasury Secretary Bentsen. Such a reform would again allow full initial deductibility of IRA contributions up to specified limits, with eligibility not contingent on lack of pension coverage. On the other hand, proposals are now floating to reduce eligibility for what is left of IRAs. Among the more sweeping reforms on the tax side that would have major effects on incentives to save is adoption of a consumption tax.

A variety of training, employment and regulatory programs in the labor market have also been suggested to foster increased employment of older individuals, and to raise the reward to work.

To understand fully the effects of these policies, we will need a more complete understanding of behavior than we currently have. We will need a better understanding not only about the behaviors of labor supply, savings and pension plan determination, but about the relations among these modes of behavior.

\footnotetext{
${ }^{88}$ For further discussions of pension policies, see Congressional Budget Office (1987) and Ippolito (1983 and 1986).
} 
APPENDIX A: TABLES and FIGURES

Table A-1: Net Worth by Family Composition, HRS Data

\begin{tabular}{|c|c|c|c|c|c|c|c|}
\hline \multirow{2}{*}{$\begin{array}{l}\text { Family } \\
\text { Composition }\end{array}$} & \multirow{2}{*}{$\begin{array}{l}\text { Sample } \\
\text { Size }\end{array}$} & \multirow{2}{*}{$\begin{array}{l}\text { Mean } \\
\text { Value } \\
(\$ 000)\end{array}$} & \multicolumn{5}{|c|}{$<-$} \\
\hline & & & 10 & 25 & 50 & 75 & 90 \\
\hline \multicolumn{8}{|c|}{ A: Net Worth Less Housing Equity } \\
\hline Couples & 5229 & 197.9 & 2.0 & 13.0 & 53.0 & 166.0 & 426.0 \\
\hline Single Men & 741 & 124.9 & 0 & 1.0 & 16.0 & 81.8 & 229.0 \\
\hline Single Women & 1632 & 55.0 & -0.7 & 0 & 7.0 & 45.0 & 140.0 \\
\hline TOTAL & 7602 & 163.0 & 0 & 6.1 & 37.1 & 130.0 & 355.0 \\
\hline \multicolumn{8}{|c|}{ B: Housing Equity } \\
\hline Couples & 5229 & 90.9 & 0 & 27.0 & 60.5 & 110.0 & 197.0 \\
\hline Single Men & 741 & 42.0 & 0 & 0 & 6.0 & 56.0 & 126.0 \\
\hline Single Women & 1632 & 42.4 & 0 & 0 & 16.5 & 58.0 & 122.0 \\
\hline TOTAL & 7602 & 76.9 & 0 & 10.0 & 50.0 & 100.0 & 177.5 \\
\hline \multicolumn{8}{|c|}{ C: Total Net Worth } \\
\hline Couples & 5229 & 288.8 & 15.0 & 56.0 & 132.8 & 285.0 & 602.0 \\
\hline Single Men & 741 & 166.9 & 0 & 4.0 & 43.0 & 157.0 & 320.5 \\
\hline Single Women & 1632 & 97.5 & 0 & 1.2 & 36.4 & 115.5 & 259.3 \\
\hline TOTAL & 7602 & 239.9 & 1.1 & 32.4 & 101.0 & 239.0 & 512.0 \\
\hline
\end{tabular}

Table A-2: Net Worth by Ethnicity, HRS Data

\begin{tabular}{|c|c|c|c|c|c|c|c|}
\hline \multirow[b]{2}{*}{ Ethnicity } & \multirow{2}{*}{$\begin{array}{c}\text { Sample } \\
\text { Size }\end{array}$} & \multirow{2}{*}{$\begin{array}{c}\text { Mean } \\
\text { Value } \\
(\$ 000)\end{array}$} & \multicolumn{5}{|c|}{$<-$} \\
\hline & & & 10 & 25 & 50 & 75 & 90 \\
\hline \multicolumn{8}{|c|}{ A: Nêt Worth Less Housing Equity } \\
\hline Black & 1424 & 45.4 & -0.9 & 0 & 5.0 & 29.0 & 91.0 \\
\hline Hispanic & 716 & 59.2 & 0 & 0.1 & 4.5 & 29.0 & 95.0 \\
\hline Other & 5462 & 189.7 & 1.3 & 11.7 & 50.0 & 160.0 & 415.9 \\
\hline TOTAL & 7602 & 163.0 & 0 & 6.1 & 37.1 & 130.0 & 355.0 \\
\hline \multicolumn{8}{|c|}{ B: Housing Equity } \\
\hline Black & 1424 & 38.6 & 0 & 0 & 17.0 & 50.0 & 89.0 \\
\hline Hispanic & 716 & 45.2 & $\overline{0}$ & $\overline{0}$ & 22.0 & 59.0 & 129.0 \\
\hline Other & 5462 & 85.4 & 0 & 20.0 & 58.0 & 107.0 & 191.0 \\
\hline TOTAL & 7602 & 76.9 & 0 & 10.0 & 50.0 & 100.0 & 177.5 \\
\hline \multicolumn{8}{|c|}{ C: Total Net Worth } \\
\hline Black & 1424 & 84.1 & 0 & 0.40 & 30.5 & 86.5 & 170.1 \\
\hline Hispanic & 716 & 104.4 & 0 & 1.7 & 34.0 & 95.5 & 224.5 \\
\hline Other & 5462 & 275.1 & 7.5 & 48.3 & 129.9 & 275.0 & 586.0 \\
\hline TOTAL & 7602 & 239.9 & 1.1 & 32.4 & 101.0 & 239.0 & 512.0 \\
\hline
\end{tabular}

Table A-3: Net Worth by Income Group, HRS Data 


\begin{tabular}{|c|c|c|c|c|c|c|c|}
\hline \multirow[b]{2}{*}{ Income } & \multirow{2}{*}{$\begin{array}{c}\text { Sample } \\
\text { Size }\end{array}$} & \multirow{2}{*}{$\begin{array}{l}\text { Mean } \\
\text { Value } \\
(\$ 000)\end{array}$} & \multicolumn{5}{|c|}{$<-\cdots-$ Percentiles $(\$ 000)-\cdots$} \\
\hline & & & 10 & 25 & 50 & 75 & 90 \\
\hline \multicolumn{8}{|c|}{ A: Nêt Worth Less Housing Equity } \\
\hline$<10 \mathrm{~K}$ & 854 & 48.6 & -0.7 & 0 & .4 & 15.0 & 48.8 \\
\hline $10-25 \mathrm{~K}$ & 1696 & 66.2 & -0.3 & 0.9 & 8.2 & 46.0 & 148.0 \\
\hline $25-50 \mathrm{~K}$ & 2405 & 96.7 & 1.2 & 9.5 & 34.0 & 97.0 & 224.2 \\
\hline $50-100 \mathrm{~K}$ & 2077 & 195.4 & 7.5 & 25.5 & 72.4 & 193.6 & 423.0 \\
\hline$>100 \mathrm{~K}$ & 570 & 665.4 & 32.0 & 90.0 & 240.0 & 695.0 & $1,792.2$ \\
\hline Total & 7602 & 163.0 & 0 & 6.1 & 37.1 & 130.0 & 355.0 \\
\hline \multicolumn{8}{|c|}{ B: Housing Equity } \\
\hline$<10 \mathrm{~K}$ & 854 & 29.3 & 0 & 0 & 0 & 35.0 & 80.0 \\
\hline $10-25 \mathrm{~K}$ & 1696 & 50.3 & 0 & 0 & 27.0 & 65.0 & 120.0 \\
\hline $25-50 \mathrm{~K}$ & 2405 & 65.3 & 0 & 17.0 & 48.0 & 85.0 & 150.0 \\
\hline $50-100 \mathrm{~K}$ & 2077 & 93.3 & 1.0 & 37.0 & 70.0 & 120.0 & 197.0 \\
\hline$>100 \mathrm{~K}$ & $570^{-}$ & 181.7 & 29.0 & 67.0 & 125.0 & 225.0 & 393.0 \\
\hline Total & 7602 & 76.9 & 0 & 10.0 & 50.0 & 100.0 & 177.5 \\
\hline \multicolumn{8}{|c|}{ C: Total Net Worth } \\
\hline$<10 \mathrm{~K}$ & 854 & 78.8 & -0.5 & 0 & 5.8 & 54.0 & 169.6 \\
\hline $10-25 \mathrm{~K}$ & 1696 & 116.5 & 0 & 7.3 & 43.5 & 120.8 & 269.0 \\
\hline $25-50 \mathrm{~K}$ & 2405 & 162.0 & 8.0 & 39.0 & 92.0 & 188.0 & 350.0 \\
\hline $50-100 \mathrm{~K}$ & 2077 & 288.6 & 35.0 & 83.7 & 165.0 & 313.1 & 590.0 \\
\hline$>100 \mathrm{~K}$ & 570 & 847.1 & 100.3 & 198.0 & 405.0 & 923.4 & $2,166.0$ \\
\hline Total & 7602 & 239.9 & 1.1 & 32.4 & 101.0 & 239.0 & 512.0 \\
\hline
\end{tabular}


Table A- 4: Total Net Worth by Family Composition and Age, AHEAD Data

\begin{tabular}{|c|c|c|c|c|c|c|c|}
\hline \multirow{2}{*}{$\begin{array}{l}\text { Family } \\
\text { Composition }\end{array}$} & \multirow{2}{*}{$\begin{array}{l}\text { Sample } \\
\text { Size }\end{array}$} & \multirow{2}{*}{$\begin{array}{l}\text { Mean } \\
\text { Value } \\
(\$ 000)\end{array}$} & \multicolumn{5}{|c|}{$<---$ Percentiles $(\$ 000)$} \\
\hline & & & 10 & 25 & 50 & 75 & 90 \\
\hline \multicolumn{8}{|c|}{ A: Age 70-74 } \\
\hline Couples & 946 & 276.3 & 17.0 & 57.0 & 140.9 & 309.0 & 578.8 \\
\hline Single Men & 233 & 201.7 & 0 & 10.0 & 65.0 & 167.0 & 367.8 \\
\hline Single Women & 825 & 178.1 & 0 & 4.1 & 51.4 & 132.5 & 295.0 \\
\hline TOTAL & 2004 & 209.2 & 0.3 & 26.6 & 90.6 & 215.0 & 462.5 \\
\hline \multicolumn{8}{|c|}{ B: Age 75-79 } \\
\hline Couples & 581 & 274.1 & 11.0 & 50.7 & 118.0 & 264.0 & 610.0 \\
\hline Single Men & 203 & 164.3 & 1.0 & 14.0 & 71.0 & 171.0 & 319.0 \\
\hline Single Women & 812 & 105.1 & 0 & 3.7 & 47.8 & 116.0 & 236.0 \\
\hline TOTAL & 1596 & 177.0 & 0.1 & 16.2 & 71.0 & 168.8 & 364.0 \\
\hline \multicolumn{8}{|c|}{ C: Age 80-84 } \\
\hline Couples & 371 & 242.2 & 10.0 & 43.5 & 114.2 & 236.0 & 495.3 \\
\hline Single Men & 154 & 148.6 & 0.5 & 10.0 & 51.0 & 132.0 & 289.0 \\
\hline Single Women & 702 & $\overline{87.5}$ & 0 & 3.5 & 40.5 & 101.5 & 188.5 \\
\hline TOTAL & 1227 & 142.7 & 0.1 & 10.2 & 60.0 & 143.0 & 290.0 \\
\hline \multicolumn{8}{|c|}{ D: 85 and up } \\
\hline Couples & 155 & 162.1 & 1.0 & 21.0 & 75.6 & 216.0 & 415.0 \\
\hline Single Men & $\overline{145}$ & 121.5 & 0 & 1.0 & 25.9 & 101.0 & 287.6 \\
\hline Single Women & 595 & 85.8 & 0 & 1.5 & 30.0 & 100.0 & 203.0 \\
\hline TOTAL & 895 & 104.7 & 0 & 2.0 & 37.0 & 111.0 & 247.0 \\
\hline
\end{tabular}


Table A-5: Net Worth Excluding Home Equity by Family Composition and Age, AHEAD Data

\begin{tabular}{|c|c|c|c|c|c|c|c|}
\hline \multirow{2}{*}{$\begin{array}{l}\text { Family } \\
\text { Composition }\end{array}$} & \multirow{2}{*}{$\begin{array}{c}\text { Sample } \\
\text { Size }\end{array}$} & \multirow{2}{*}{$\begin{array}{l}\text { Mean } \\
\text { Value } \\
(\$ 000)\end{array}$} & \multicolumn{5}{|c|}{$<\ldots$} \\
\hline & & & 10 & 25 & 50 & 75 & 90 \\
\hline \multicolumn{8}{|c|}{ A: Age 70-74 } \\
\hline Couples & 946 & 176.6 & 1.0 & 11.0 & 55.7 & 190.0 & 420.0 \\
\hline Single Men & 233 & 140.3 & 0 & 2.1 & 17.0 & 89.0 & 255.4 \\
\hline Single Women & 825 & 68.3 & 0 & 0.1 & 7.5 & 50.0 & 160.5 \\
\hline TOTAL & 2004 & $\overline{129.6}$ & 0 & 2.2 & 25.9 & 109.2 & 323.0 \\
\hline \multicolumn{8}{|c|}{ B: Age 75-79 } \\
\hline Couples & 581 & 176.8 & 0.8 & 10.0 & 38.0 & 150.0 & 417.0 \\
\hline Single Men & 203 & 80.2 & 0 & 2.0 & 15.5 & 83.0 & 205.0 \\
\hline Single Women & 812 & 53.0 & 0 & 0.2 & 7.0 & $\overline{39.5}$ & 125.0 \\
\hline TOTAL & 1596 & $\overline{103.6}$ & 0 & 1.3 & 15.8 & 76.3 & 247.0 \\
\hline \multicolumn{8}{|c|}{ C: Age 80-84 } \\
\hline Couples & 371 & 161.3 & 1.0 & 8.0 & 37.0 & 139.0 & 370.3 \\
\hline Single Men & 154 & 107.5 & 0.1 & 1.2 & 19.5 & 66.8 & 224.0 \\
\hline Single Women & 702 & 42.7 & 0 & 0.2 & 5.1 & 40.0 & 112.0 \\
\hline TOTAL & 1227 & 87.2 & 0 & 1.0 & 12.2 & 64.1 & 191.0 \\
\hline \multicolumn{8}{|c|}{ D: 85 and up } \\
\hline Couples & 155 & 104.8 & 0 & 2.0 & 20.0 & 125.0 & 271.0 \\
\hline Single Men & 145 & 74.8 & 0 & 0.4 & 7.0 & 45.0 & 114.5 \\
\hline Single Women & 595 & 48.1 & 0 & 0 & 5.0 & 33.2 & 113.0 \\
\hline TOTAL & 895 & $\overline{62.2}$ & 0 & 0.2 & 6.7 & 50.0 & 140.0 \\
\hline
\end{tabular}


Table A-6: Total Net Worth by Ethnicity and Age, AHEAD Data

\begin{tabular}{|c|c|c|c|c|c|c|c|}
\hline \multirow[b]{2}{*}{ Ethnicity } & \multirow{2}{*}{$\begin{array}{c}\text { Sample } \\
\text { Size }\end{array}$} & \multirow{2}{*}{$\begin{array}{l}\text { Mean } \\
\text { Value } \\
(\$ 000)\end{array}$} & \multicolumn{5}{|c|}{$<---{ }_{-}$} \\
\hline & & & 10 & 25 & 50 & 75 & 90 \\
\hline \multicolumn{8}{|c|}{ A: Age 70-74 } \\
\hline Black & 309 & 50.4 & 0 & $\overline{0}$ & 25.0 & 69.0 & 152.0 \\
\hline Hispanic & 130 & $7 \overline{2.8}$ & 0 & 0 & 25.5 & 67.0 & 181.2 \\
\hline White + Other & 1565 & 238.5 & 5.5 & 45.5 & 116.2 & 262.2 & 522.0 \\
\hline TOTAL & 2004 & 209.2 & 0.3 & 26.6 & 90.6 & 215.0 & 462.5 \\
\hline \multicolumn{8}{|c|}{ B: Age 75-79 } \\
\hline Black & 241 & 51.6 & 0 & 0.8 & 25.0 & 56.2 & 113.0 \\
\hline Hispanic & 90 & 42.6 & 0 & 0 & 1.0 & 43.0 & 99.0 \\
\hline White + Other & 1265 & 200.1 & 2.0 & 33.2 & 94.0 & 202.0 & 409.0 \\
\hline TOTAL & 1596 & 177.0 & 0.1 & 16.2 & 71.0 & 168.8 & 364.0 \\
\hline \multicolumn{8}{|c|}{ C: Age 80-84 } \\
\hline Black & 184 & 61.7 & 0 & 0.6 & 31.0 & 62.0 & 130.0 \\
\hline Hispanic & 71 & 64.5 & 0 & 0 & 15.0 & 50.0 & 101.5 \\
\hline White + Other & 972 & 159.0 & 0.8 & 20.0 & 77.7 & 166.5 & 332.0 \\
\hline TOTAL & 1227 & 142.7 & 0.1 & 10.2 & 60.0 & 143.0 & 290.0 \\
\hline \multicolumn{8}{|c|}{ D: 85 and up } \\
\hline Black & 126 & 39.5 & 0 & 0 & 5.0 & 45.0 & 122.0 \\
\hline Hispanic & 44 & 31.9 & 0 & 0 & 0.3 & 62.8 & 75.0 \\
\hline White + Other & 725 & 116.4 & 0 & 5.5 & 46.2 & 131.0 & 270.0 \\
\hline TOTAL & 895 & 104.7 & 0 & 2.0 & 37.0 & 111.0 & 247.0 \\
\hline
\end{tabular}


Table A-7: Net Worth Excluding Home Equity by Ethnicity and Age, AHEAD Data

\begin{tabular}{|c|c|c|c|c|c|c|c|}
\hline \multirow[b]{2}{*}{ Ethnicity } & \multirow{2}{*}{$\begin{array}{c}\text { Sample } \\
\text { Size }\end{array}$} & \multirow{2}{*}{$\begin{array}{c}\text { Mean } \\
\text { Value } \\
(\$ 000)\end{array}$} & \multicolumn{5}{|c|}{$<-\cdots$} \\
\hline & & & 10 & 25 & 50 & 75 & 90 \\
\hline \multicolumn{8}{|c|}{ A: Age 70-74 } \\
\hline Black & 309 & 20.3 & 0 & 0 & 1.0 & 16.0 & 60.0 \\
\hline Hispanic & 130 & 25.5 & 0 & 0 & 0.5 & 8.0 & 48.8 \\
\hline White + Other & 1565 & 150.3 & 0.5 & 7.0 & 41.2 & 150.0 & 365.0 \\
\hline TOTAL & 2004 & 129.6 & 0 & 2.2 & 25.9 & 109.2 & 323.0 \\
\hline \multicolumn{8}{|c|}{ B: Age 75-79 } \\
\hline Black & 241 & 20.9 & -0.5 & 0 & 0.8 & 10.0 & 40.0 \\
\hline Hispanic & 90 & 11.9 & -0.6 & 0 & $\overline{0}$ & 2.0 & 20.3 \\
\hline White + Other & 1265 & 119.0 & $\overline{0.3}$ & 5.3 & 26.0 & 101.0 & 297.0 \\
\hline TOTAL & 1596 & 103.6 & 0 & 1.3 & 15.8 & 76.3 & 247.0 \\
\hline \multicolumn{8}{|c|}{ C: Age 80-84 } \\
\hline Black & 184 & 23.0 & 0 & 0 & 1.0 & 13.1 & 45.5 \\
\hline Hispanic & 71 & 27.7 & 0 & 0 & 0.3 & 5.2 & 35.0 \\
\hline White + Other & 972 & 99.9 & 0 & 2.4 & 20.4 & 83.3 & 224.0 \\
\hline TOTAL & 1227 & 87.2 & 0 & 1.0 & 12.2 & 64.1 & 191.0 \\
\hline \multicolumn{8}{|c|}{ D. 85 and up } \\
\hline Black & 126 & 14.9 & 0 & 0 & 0.2 & 9.5 & 40.0 \\
\hline Hispanic & 44 & 7.9 & 0 & 0 & 0 & 2.5 & 30.0 \\
\hline White + Other & 725 & 70.8 & 0 & 1.0 & 10.5 & 61.0 & 179.0 \\
\hline TOTAL & 895 & 62.2 & 0 & 0.2 & 6.7 & 50.0 & 140.0 \\
\hline
\end{tabular}


FIGURE A-1

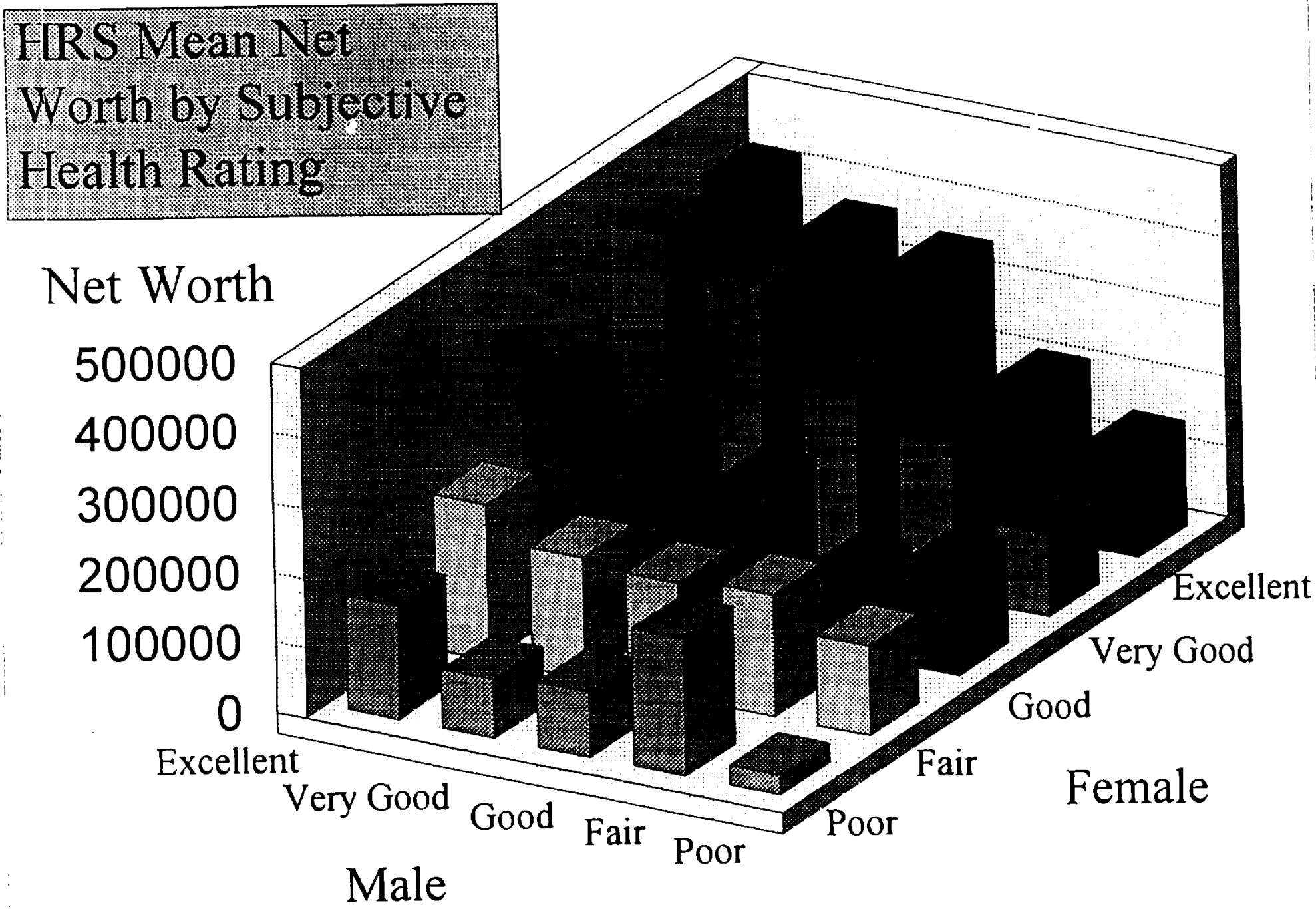


FIGURE A-2

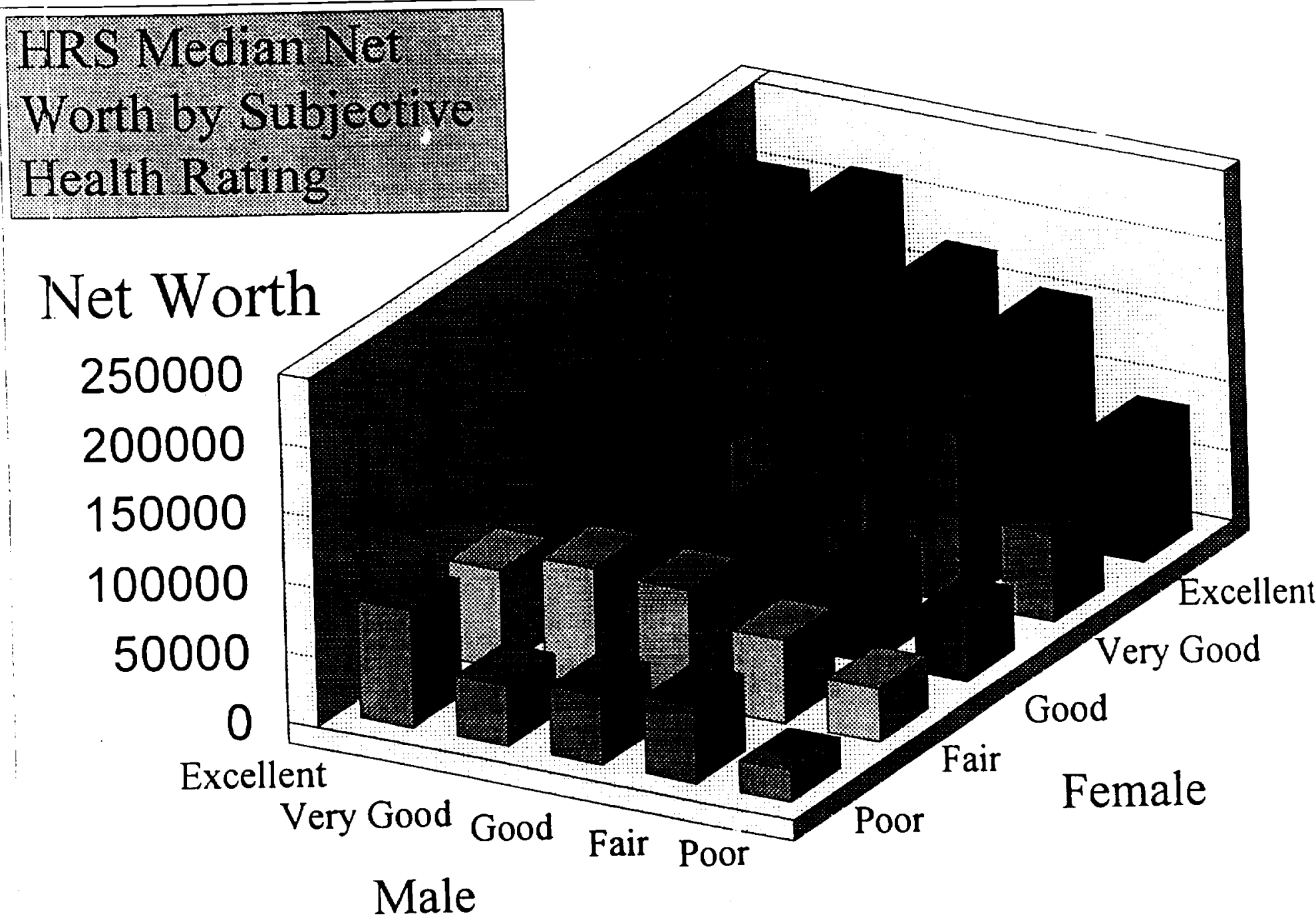




\section{HIRS Mean Income by Subjective \\ Health Rating

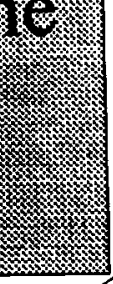

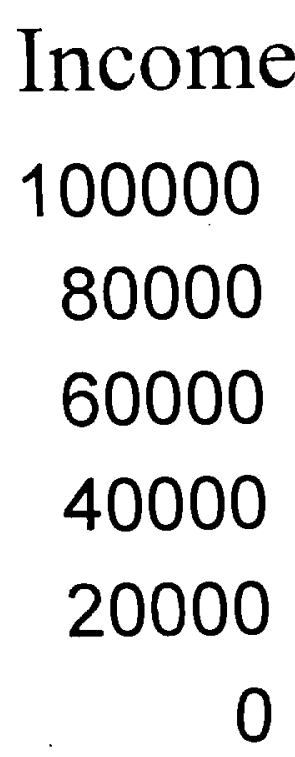

Excellent

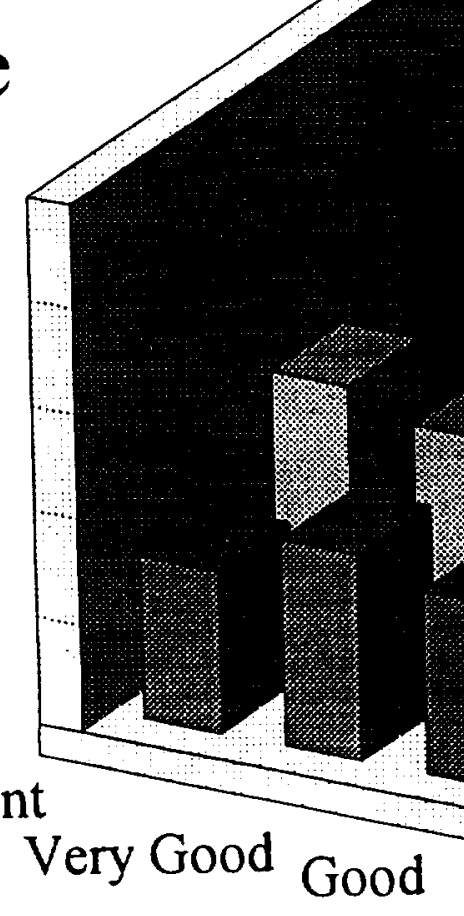

Male

\section{FIGURE A-3}

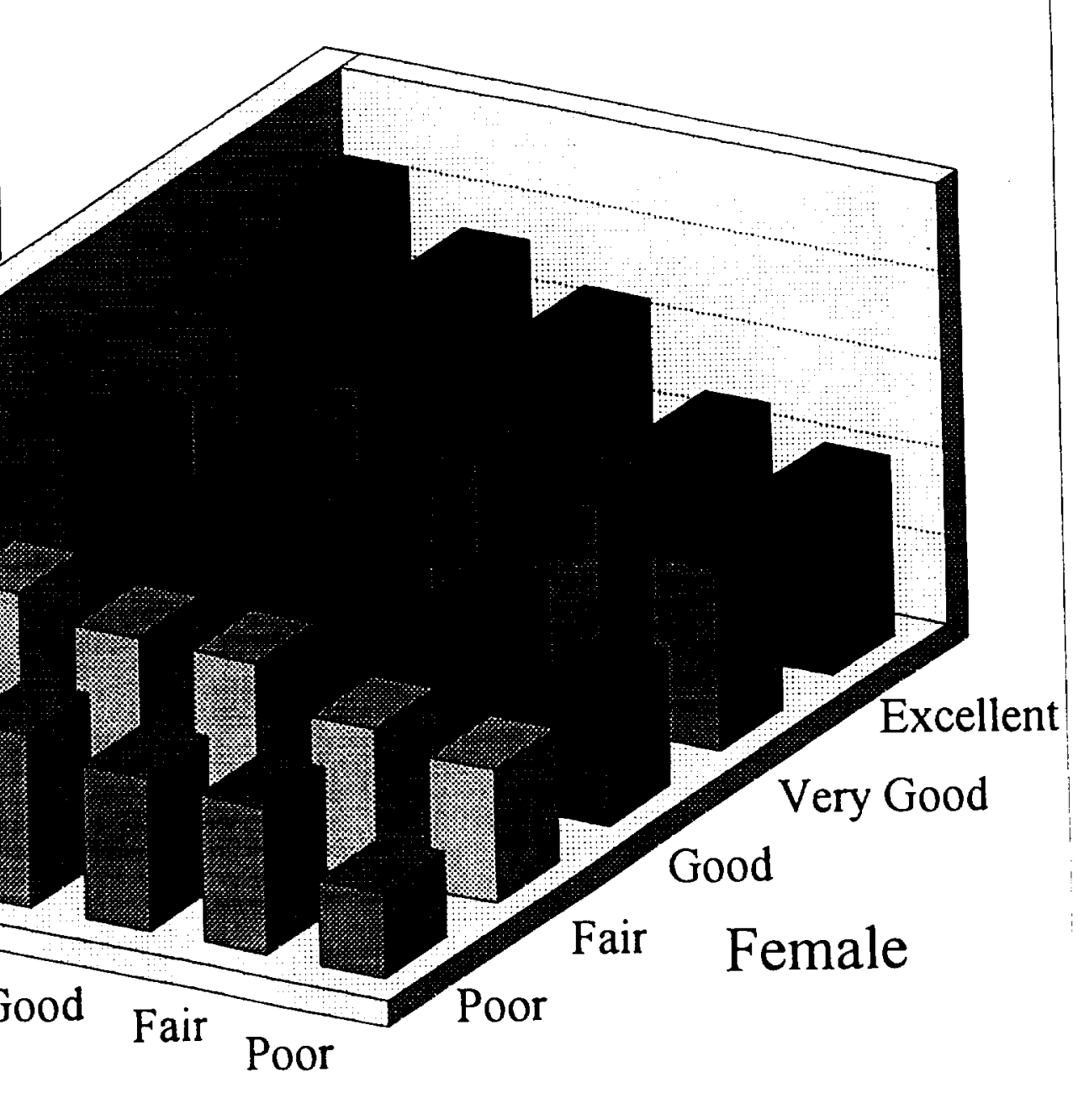


FIGURE A-4

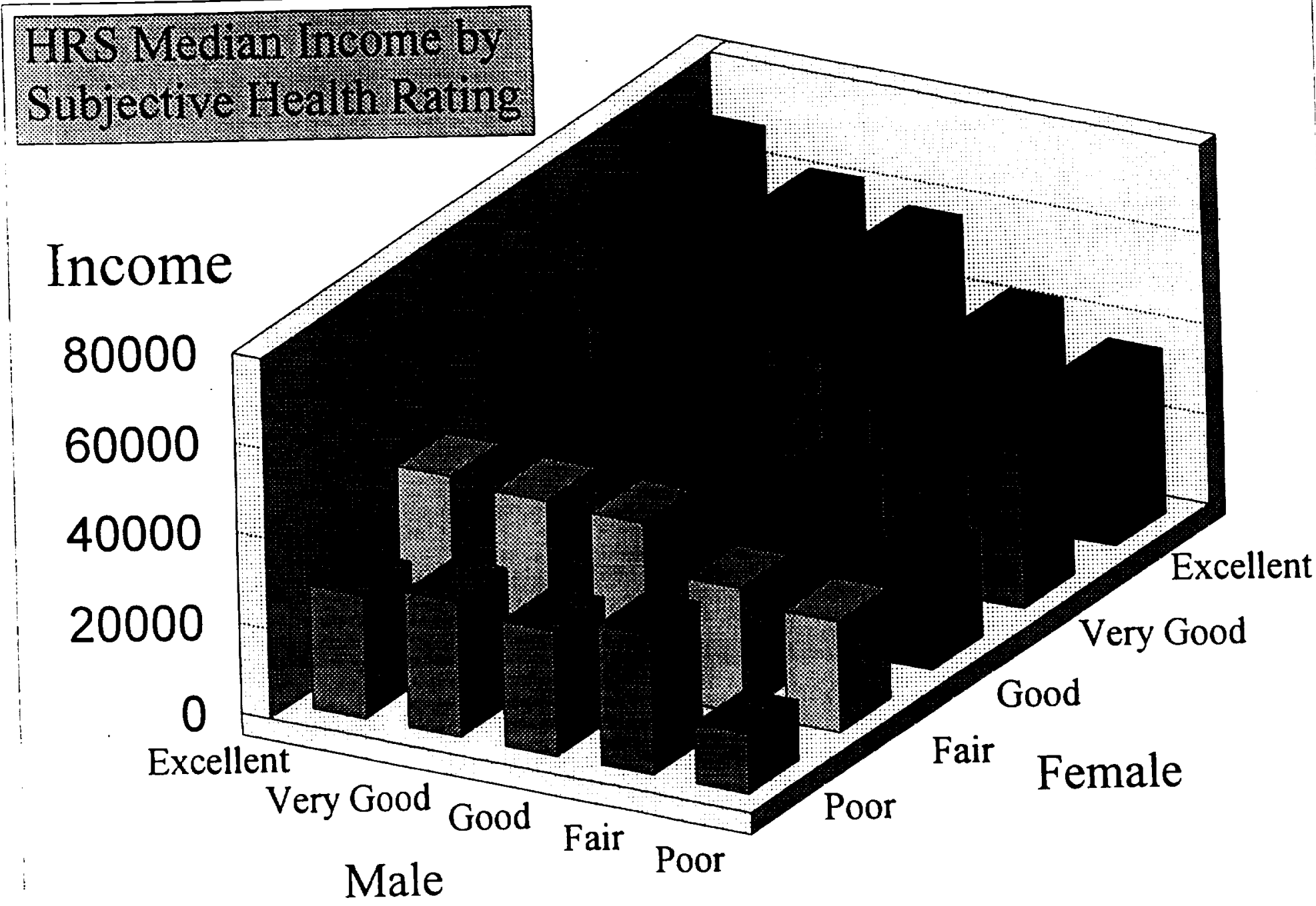




\section{References}

Abel, Andrew B. 1985. "Precautionary Savings and Accidental Bequests." American Economic Review 75(4): 777-791.

Allen, Steven G.; Robert L. Clark and Ann A. McDermed. 1992a. "Pension Bonding and Lifetime Jobs". Journal of Human Resources 28(3): 463-81.

Allen, Steven G.; Robert L. Clark and Ann A. McDermed. 1992b. "Postretirement Benefit Increases in the 1980s". In John A. Turner and Daniel J. Beller, editors. Trends in Pensions. Washington, D.C.: GPO 319-340.

Allen, Steven G.; Robert L. Clark. and Daniel Sumner. 1986. "Post Retirement Adjustments of Pensions". Journal of Human Resources, Vol. 21, No. 1 (Winter), pp. 118-137.

Anderson, Patricia M., Alan L. Gustman, and Thomas L. Steinmeier. 1994. "The Trend To Earlier Retirement Among Males". Report to the Social Security Administration.

Ausink, John and David A. Wise. 1993. "The Military Pension Compensation and Retirement of Air Force Pilots". Paper presented at NBER Conference On The Economic s of Aging.

Barro, Robert J. 1974. "Are Government Bonds Net Wealth?". Journal of Political Economy 82(6): 675-692.

Barsky, Robert, Miles Kimball, Matthew Shapiro and F. Thomas Juster. 1993. "Experimental Measures of Preferences In The HRS". Paper presented at Health and Retirement Survey Early Results Workshop, Survey Research Center, University of Michigan.

Becker, Gary S. 1991. A Treatise On the Family. Cambridge, Mass.: Harvard Press.

Berkovec, James C. and Steven Stern. 1991. "Job Exit Behavior of Older Men". Econometrica 59 (1): $189-210$.

Bernheim, B. Douglas. 1988. "Social Security Benefits: An Empirical Study of Expectations and Realizations". In R. Ricardo Campbell and E. Lazear, eds., Issues In Contemporary Retirement. Stanford: Hoover Institution: 312-345.

1989. "The Timing of Retirement: A Comparison of Expectations and Realizations." In David A. Wise, ed., The Economics of Aging. Chicago: The University of Chicago Press: $335-55$.

899-927. . 1991. "How Strong Are Bequest Motives?" Journal of Political Economy 99(5):

1993a. "Personal Saving, Information, and Economic Literacy: New Directions for Public Policy". Unpublished manuscript, Department of Economics, Princeton University, May.

1993b. "Is the Baby generation preparing adequately for retirement?"

New York: Merrill Lynch, 1993b. Unpublished manuscript, Department of Economics, Princeton University, October. 
. 1994. "Do Saving Incentives Work?: A Discussion of Engen, Gale and Scholz". Brookings Papers On Economic Activity.

Bernheim, B. Douglas and Scholz, John Karl. 1993. "Private Saving and Public Policy". Tax Policy and the Economy 7: 73-110.

Bernheim, B. Douglas, Andrei Shleifer and Lawrence Summers. 1985. "The Strategic Bequest Motive". Journal of Political Economy 96(6): 1045-1076. December.

Blau, David M. 1994. "Labor Force Dynamics of Older Men". Econometrica 62(1): 117-156.

Bloom, David E. and Richard B. Freeman. 1992. "The Fall In Private Pension Coverage In The U.S.". American Economic Review, Papers and Proceedings 82(2) 539-545.

Bodie, Zvi. 1990. "Pensions As Retirement Income Insurance." Journal of Economic Literature, Vol. 28, No. 1 (March), pp. 28-49.

Borsch-Supan, Axel. 1989. "Household Dissolution and The Choice of Alternative Living Arrangements Among Elderly Americans". in David a Wise, editor. The Economics of Aging. University of Chicago Press.

1990. "A Dynamic Analysis of Household Dissolution and Living Arrangement Transitions by Elderly Americans". In David A. Wise, editor, Issues In The Economics of Aging. University of Chicago Press: 89-114.

Borsch-Supan, Axel, McFadden, Daniel and Schnabel. 1993. Mimeo.

Borsch-Supan, Axel and Konrad Stahl. 1991. "Life Cycle Savings and Consumption Constraints. Theory, Empirical Evidence and Fiscal Implications". Journal of Population Economics 86: 3-27.

Brown, Charles. 1993. "Early Retirement Windows: Windows of Opportunity? Defenestrations? (and even refenestrations...)." Paper presented at Health and Retirement Survey Early Results Workshop, Survey Research Center, University of Michigan.

Burkhauser, Richard V., Karen C. Holden and Daniel Feaster. 1988. "Incidence, Timing, and Events Associated with Poverty: A Dynamic View of Poverty in Retirement". Journal of Gerontology 43(2): S46-52.

Burkhauser, Richard V. 1979. "The Pension Acceptance Decision of Older Workers." Journal of Human Resources, Vol. 14, No. 1 (Winter), pp. 63-75.

Burtless, Gary and Robert A. Moffitt. 1984. "The Effect Of Social Security Benefits On The Labor Supply Of The Aged". In Retirement And Economic Behavior, eds. Henry Aaron and Gary Burtless, 135-74. Washington, D.C.: Brookings Institution.

Burtless, Gary and Robert A. Moffitt. 1985. "The Joint Choice Of Retirement Age And Post Retirement Hours Of Work", Journal Of Labor Economics 3: 209-236.

Cagan, Philip. 1965. "The Effect of Pension Plans on Aggregate Saving: Evidence from a Sample Survey." NBER Occasional Paper 95. New York: Columbia University Press. 
Carroll, Christopher D. 1992. "The Buffer Stock Theory of Savings: Some Macroeconomic

Evidence". Brookings Papers On Economic Activity 2: 61-135.

Carroll, Christopher D. and Andrew A. Samwick. 1994. "The Nature of Precautionary Wealth". Cambridge, NBER, unpublished manuscript.

Carroll, Christopher D. and Lawrence H. Summers. 1991. "Consumption Growth Parallels Income Growth: Some New Evidence". In Douglas B. Bernheim and John B. Shoven, editors. National Saving and Economic Performance. University of Chicago Press: 305-343.

Clark, Robert L. and Ann A. McDermed. 1990. The Choice of Pension Plans In A Changing Regulatory Environment. Washington, D.C.: American Enterprise Institute.

Congressional Budget Office. 1987. Tax Policy For Pensions And Retirement Savings. Washington, D.C.: U.S. Government Printing Office, April.

1993. Baby Boomers In Retirement: An Early Perspective.

Davies, James B. "Uncertain Lifetime, Consumption, and Dissaving in Retirement", Journal of Political Economy 89: 561-76.

Deaton, Angus. 1991. Econometrica 59(5): 1221-1248.

Employee Benefit Research Institute. 1992. "New Findings from the March 1991 CPS on Pension Coverage and Participation". Employee Benefit Notes, March.

. 1992. Databook On Employee Benefits.

1993. "Pension Coverage and Participation Growth: A New Look at Primary and Supplemental Plans", EBRI Issue Brief No. 144.

. 1994a. Notes, Vol 15, No. 4, April.

. 1994b. "Characteristics of The Part-Time Work Force: Analysis of the March

1993 Current Population Survey".

Engelhardt, Gary V. 1994. "House Prices and Home Owner Saving Behavior". Dartmouth College mimeo, July, 1994.

Engen, Eric H. and William Gale. 1993. "IRAs and Saving in a Stochastic Life-Cycle Model. Mimeo.

Even, William E. and David A. Macpherson. 1993. "The Pension Coverage of Young and Mature Men". Report to the U.S. Department of Labor.

Feinstein, Jonathan and Daniel McFadden. 1989. "The Dynamics of Housing Demand by the Elderly: Wealth, Cash Flow and Demographic Effects". In David A. Wise, editor, The Economics of Aging. University of Chicago Press.

Fields, Gary S. and Olivia S. Mitchell. Retirement, Pensions and Social Security. Cambridge: MIT 
Press, 1984.

Gale, William G. and John K. Scholz. 1994. "IRAs and Household Saving". American Economic Review.

Garber, Alan M. and Thomas E. MaCurdy. 1990. "Predicting Nursing Home Utilization By High Risk Elderly". In David A. Wise, editor. Issues In The Economics of Aging. University of Chicago Press.

Grad, Susan. 1994. Income of the Population 55 or Older, 1992. Washington, D.C., U.S. Department of Health and Human Services, Social Security Administration.

Green, Jerry. 1985. "The Riskiness Of Private Pensions." In David A. Wise, ed., Pensions, Labor, and Individual Choice. Chicago: The University of Chicago Press, pp. 357-375.

Guiso, L., T. Jappelli and d Terlizzese. 1992. "Earnings Uncertainty and Precautionary Saving". Journal of Monetary Economics 30: 307-337.

Gustman, Alan L. and Olivia S. Mitchell. 1992. "Pensions and the Labor Market: Behavior and Data Requirements". In Pensions and the U.S. Economy: The Need for Good Data, eds. Zvi Bodie and Alicia Munnell, 39-87. Philadelphia, Pa: Pension Research Council.

Gustman, Alan L., Olivia S. Mitchell and Thomas L. Steinmeier. 1993. "Retirement Research Using The Health and Retirement Survey". Paper presented at Health and Retirement Survey Early Results Workshop, Survey Research Center, University of Michigan.

Relations Review 47(3).

1994. "The Role of Pensions In The Labor Market". Industrial and Labor

Gustman, Alan. L. and Thomas L. Steinmeier. 1983. "Minimum Hours Constraints And Retirement Behavior". Contemporary Policy Issues, a Supplement to Economic Inquiry 3: 77-91.

. 1984. "Partial Retirement and The Analysis of Retirement Behavior". Industrial and Labor Relations Review 37(3): 403-415.

- 1985a. "The 1983 Social Security Reforms and Labor Supply Adjustments of Older Individuals in the Long Run," Journal of Labor Economics, Vol. 3, 1985, pp. 237-253.

. 1985b. "The Effects of Partial Retirement on Wage Profiles of Older Workers". Industrial Relations 24(2): 257-265.

. 1986a. "A Structural Retirement Model." Econometrica 54(3): 555-584.

. 1986b. "A Disaggregated Structural Analysis of Retirement By Race, Difficulty of Work and Health". Review of Economics And Statistics 67(3): 509-513.

. 1989. "An Analysis of Pension Benefit Formulas, Pension Wealth and Incentives From Pensions". Research In Labor Economics 10: 33-106.

. 1991. "Changing The Social Security Rules For Work After 65", Industrial 
And Labor Relations Review 44(4): 733-745.

1992. "The Stampede Towards Defined Contribution Pension Plans: Fact or

Fiction?". Industrial Relations 31(2): 361-69.

. 1993a. "Cost of Living Adjustments In Pensions." In Olivia S. Mitchell, ed., As the Workforce Ages: Costs, Benefits And Policy Challenges. Ithaca: Cornell University Press, pp. 147-182.

. 1993b. "Pension Portability And Labor Mobility: Evidence From The Survey Of Income And Program Participation". Journal of Public Economics 50: 299-323.

. 1994. "Retirement In A Family Context: A Structural Model For Husbands and Wives". NBER Working Paper 4629.

. "Employer Provided Health Insurance and Retirement Behavior", Industrial and Labor Relations Review, October, 1994 (forthcoming).

. Forthcoming. Pension Incentives And Job Mobility. Upjohn Institute, 1994.

Hall, Robert E. and Frederick S. Mishkin. 1982. "The Sensitivity of Consumption to Transitory Income: Estimates from Panel Data on Households". Econometrica 50(2): 461-482.

Hamermesh, Daniel S. 1984. "Consumption during Retirement: The Missing Link in the Life Cycle". Review of Economics and Statistics 66(1): 1-7.

Hoynes, Hilary and Daniel McFadden. 1994. "The Impact of Demographics on Housing and nonHousing Wealth in the United States." NBER Working Paper No. 4666.

Hubbard, R. Glenn, Jonathan Skinner and Stephen P. Zeldes. 1994a. "Expanding the Life-Cycle Model: Precautionary Saving and Public Policy". American Economic Review 84(2): 174-179.

. 1994b. "The Importance of Precautionary Motives in Explaining Individual and

Aggregate Saving". Carnegie-Rochester Conference Series on Public Policy.

Economy. . Forthcoming. "Precautionary Saving and Social Insurance. Journal of Political

Hurd, Michael. 1987. "Savings of the Elderly and Desired Bequests". American Economic Review 77(3): 298-312.

. 1990a. "Research On The Elderly: "Economic Status, Retirement and

Consumption and Saving". Journal of Economic Literature 28(2): 565-637.

. 1990b. "The Joint Retirement Decisions of Husbands and Wives". In David A. Wise, editor, Issues In The Economics of Aging. Chicago: University of Chicago Press: 231-254.

. 1993. "The Effect of Labor Market Rigidities on the Labor Force Behavior of Older Workers". NBER Working Paper 4462.

Hurd, Michael and Kathleen McGarry. 1993a. "The Relationship Between Job Characteristics and Retirement". Paper presented at Health and Retirement Survey Early Results Workshop, Survey 
Research Center, University of Michigan. NBER Working Paper 4558.

. 1993b. Evaluation of Subjective Probability Distributions In The HRS". Paper

presented at Health and Retirement Survey Early Results Workshop, Survey Research Center,

University of Michigan. NBER Working Paper 4560.

Hurd, Michael and David A. Wise. 1989. "The Wealth and Poverty of.Widows: Assets Before and After the Husband's Death". In David Wise, editor, The Economics of Aging. University of Chicago Press: 177-200.

Hutchens, Robert. "Delayed Payment Contracts and a Firm's Propensity to Hire Older Workers," Journal Of Labor Economics, October, 1986, 4(4), pp. 439-457.

- 1987. "A Test of Lazear's Theory of Delayed Payment Contract." Journal of

Labor Economics, Vol. 5, No. 4 (October), Part 2, pp. S153-170.

Ippolito, Richard. 1983. "Public Policy Toward Private Pensions". Contemporary Policy Issues, a Supplement to Economic Inquiry 3: 53-76.

. 1985a. "The Labor Contract and True Economic Pension Liabilities." American

Economic Review, Vol. 75, No. 5 (December), pp. 1031-1043.

. 1985b. "The Economic Function of Underfunded Pension Plans." The Journal of

Law and Economics, Vol. 28, No. 3 (October), pp. 611-651.

1986. Pensions, Economics and Public Policy. Pension Research Council.

Homewood, Illinois: Dow Jones-Irwin.

. 1987. "The Implicit Pension Contract: Developments and New Directions."

Journal of Human Resources, Summer , 22(3), pp. 441-464.

. 1990. "Toward Explaining Earlier Retirement After 1970", Industrial and Labor

Relations Review, Vol. 43, No. 5 (July), pp. 556-569.

. Forthcoming. "Toward Explaining The Growth of Defined Contribution Pension

Plans". Industrial Relations.

Juster, F. Thomas and James P. Smith. 1994. "Improving The Quality Of Economic Data: Lessons From The HRS". Mimeo. Ann Arbor, Michigan.

Juster, F. Thomas and Frank P. Stafford. 1991. "The Allocation of Time: Empirical Findings, Behavioral models, and Problems of Measurement". Journal of Economic Literature 29: 471-522.

Karoly, Lynn A. and Jeannette A. Rogowski. 1994. "The Effects of Health Insurance on the Decision to Retire". Industrial and Labor Relations Review 48(1).

Katona, George. 1965. Private Pensions and Individual Saving. Ann Arbor, MI: Survey Research Center, University of Michigan.

Kimball, Miles S. 1990. "Precautionary Saving in the Small and The Large". Econometrica 58: 53- 
73.

. 1993. "Standard Risk Aversion". Econometrica 61(3): 589-611.

Kotlikoff, Laurence J. 1988. "Intergenerational Transfers and Savings". The Journal of Economic Perspectives 2(2): 41-58.

Kotlikoff, Laurence J. and Spivak, Avia. 1981. "The Family as an Incomplete Annuities Market," Journal of Political Economy, April, 89(2), pp. 372-91.

Kotlikoff, Laurence J. and Lawrence Summers. 1981. "The Role of Intergenerational Transfers In Capital Accumulation". Journal of Political Economy 89(4): 706-732.

Kotlikoff, Laurence J. and David A. Wise. 1985. "Labor Compensation and The Structure of Private Pension Plans: Evidence For Contractual vs. Spot Labor Markets". In David A. Wise, ed., Pensions, Labor, and Individual Choice. Chicago: The University of Chicago Press, pp. 55-85.

1987. "The Incentive Effects of Private Pension Plans," In Zvi Bodie and John B. Shoven and David A. Wise eds., Issues in Pension Economics. Chicago: University of Chicago Press, pp. 283-336.

Kruse, Douglas L. Forthcoming. "Pension Substitution In The 1980's: Why The Shift Toward Defined Contribution Pension Plans?" Industrial Relations.

Lazear, Edward P. 1979. "Why Is There Mandatory Retirement," Journal of Political Economy 87(6), pp. 1261-1284.

. 1983. "Pensions as Severance Pay." In Zvi Bodie and John B. Shoven and David A. Wise eds., Financial Aspects of the United States Pension System. Chicago: The University of Chicago Press, , pp. 57-85.

Lumsdaine, Robin and David A. Wise. 1990. "Aging and Labor Force Participation: A Review of Trends and Explanations". NBER Working Paper No. 3420.

Lumsdaine, Robin; James Stock and David A. Wise. 1990. "Efficient Windows And Labor Force Reduction", Journal of Public Economics 43: 131-159.

1992a. "Three Models of Retirement: Computational Complexity versus

Predictive validity", in David Wise, editor, Topics In The Economics of Aging, Chicago: University of Chicago Press, pp. 19-57.

. 1992b. "Pension Plan Provisions And Retirement: Men \& Women, Medicare, And Models". NBER Working Paper 4201.

Luzadis, Rebecca A. and Olivia S. Mitchell. 1991. "Explaining Pension Dynamics". Journal of Human Resources 26(4): 679-703.

McGarry, Kathleen and Robert F. Schoeni. 1994. "Transfer Behavior: Measurement and the Redistribution of Resources Within the Family. Paper presented at Health and Retirement Survey Early Results Workshop, SRC, University of Michigan. Revised. 
Mitchell, Olivia S. 1988. "Worker Knowledge of Pension Provisions". Journal of Labor Economics 6(1): 28-39.

. 1992. "Trends In Pension Benefit Formulas And Retirement Provisions". In

Turner, John A. and Daniel J. Beller. Trends In Pensions, 1992. Washington, DC: U.S.

Government Printing Office: 177-216.

Mitchell, Olivia S. and Rebecca A. Luzadis. 1988 "Changes In Pension Incentives Through Time." Industrial and Labor Relations Review, Vol. 42, No 1 (October), pp. 100-108.

Modigliani, Franco. 1988. "The Role of Intergenerational Transfers and Life Cycle Saving in the Accumulation of Wealth". The Journal of Economic Perspectives 2(2): 15-40.

Munnell, Alicia H. and Frederick O. Yohn. "What Is The Impact Of Pensions On Savings?". In Pensions and the U.S. Economy: The Need for Good Data, eds. Zvi Bodie and Alicia Munnell, Philadelphia, Pa: Pension Research Council: 39-87.

Nalebuff, Barry and Zeckhauser, Richard J. "Pensions And The Retirement Decision", in Pensions, Labor, and Individual Choice. Ed. David A. Wise. Chicago: The University of Chicago Press, 1985, pp. 283-316.

Parsons, Donald O. 1980a. "The Decline of Male Labor Force Participation". Journal of Political Economy, February, pp. 117-134.

. 1980b. " Racial Trends In Male Labor Force Participation". American Economic Review, December, pp. 911-920.

1991. "The Decline In Private Pension Coverage In The United States".

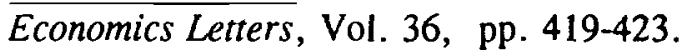

. 1993. "The Contraction In Pension Coverage". Mimeo.

Peracchi, Franco and Finis Welch. 1994. "Trends In Labor Force Transitions of Older Men and Women". Journal of Labor Economics. 12(2): pp. 210-242.

Poterba, James M. Forthcoming. Mimeo.

Poterba, James M., Steven F. Venti and David A. Wise. 1993. "Do 401(k) Plans Crowd Out Other Retirement Savings?" NBER Working Paper 4391.

1994. "Targeted Retirement Saving and the Net Worth of Elderly Americans".

American Economic Review 84(2): 180-185.

Reimers, Cordelia and Marjorie Honig. 1993a. "The Perceived Budget Constraint under Social Security: Evidence from Reentry Behavior". Journal of Labor Economics 11(1) pt. 1: 184-204.

- 1993b. "Responses To Social Security By Men And Women: Myopic And Far-

Sighted Behavior". Presented at 1993 Meeting, APPAM. 
Ruhm, Christopher J. 1992. "Secular Changes in the Work and Retirement Patterns of Older Men". Mimeo.

Rust, John. 1989. "A Dynamic Programming Model of Retirement Behavior". In David A. Wise, editor, The Economics of Aging. University of Chicago Press: 359-398.

. 1990. "Behavior of Male Workers At The End Of The Life Cycle: An Empirical Analysis Of States And Controls". In Issues in the Economics of Aging, ed. David A. Wise, 317-379. Chicago: University of Chicago Press.

. 1993. "Evaluation of the HRS and RHS from a Decision-Theoretic Perspective". Paper presented at Health and Retirement Survey Early Results Workshop, Survey Research Center, University of Michigan.

Rust, John and Christopher Phelan. 1993. "How Social Security and Medicare affect retirement behavior in a world of incomplete markets". Mimeo.

Samwick, Andrew A. 1993a. "The Joint Effect of Social Security and Pensions on the Timing of Retirement: Some New Evidence". Mimeo.

Mimeo. . 1993b. "Wage Risk Compensation Through Employer-Provided Pensions".

. 1994. "The Limited Offset Between Pension Wealth and Other Private Wealth: Implications of Buffer Stock Saving". Unpublished. Cambridge, 1994.

Sheiner, Louise and David Weil. 1992. "The Housing Wealth of The Aged". NBER Working Paper No. 4115.

Skinner, Jonathan. 1988. "Risky Income, Life-Cycle Consumption and Precautionary Savings". Journal of Monetary Economics 22: 237-255.

. 1993. "Is Housing Wealth a Sideshow?" NBER Working Paper No. 4552.

Smith, James P. 1994. "Marriage, Assets, And Savings". Rand, mimeo, July.

Soldo, Beth J. and Martha S. Hill. 1993. "Family Structure and Transfer Measures In The HRS: Background and Overview". Paper presented at Early Results Workshop, SRC, University of Michigan.

Stern, Steven and Petra Todd. 1993. "A Test of Lazear's Mandatory Retirement Model". Mimeo, 1993.

Stock, James H. and David A. Wise. 1990a. "The Pension Inducement to Retire: An Option Value Analysis". In Issues In The Economics of Aging, ed., David A. Wise, 205-224. Chicago: University of Chicago Press.

58(5): $1151-1180$.

1990b. "Pensions, The Option Value Of Work, And Retirement". Econometrica, 
Thaler, Richard H. 1994. "Psychology and Savings Policy". American Economic Review 84(2): 186-192

Turner, John A. and Daniel J. Beller. 1992. Trends In Pensions, 1992. Washington, DC: U.S. Government Printing Office.

Venti, Steven F. and David A. Wise. 1987. "IRAs and Saving". In Martin Feldstein, editor. The Effects of taxation on Capital Accumulation. University of Chicago Press.

. 1989. "Aging, Moving and Housing Wealth". In David A. Wise, editor. The Economics of Aging. University of Chicago Press: $9-52$.

. 1990. "But They Don't Want To Reduce Housing Equity", in David A. Wise, editor, Issues In The Economics of Aging. University of Chicago Press: 13-29.

. 1993. "The Wealth of Cohorts and the Changing Assets of Older Americans".

NBER Working Paper No. 4600.

Wise, David A. and Richard G. Woodbury. 1994. "Policy Toward The Aged". In Martin Feldstein, Editor, American Economic Policy In The 1980s. Chicago: University of Chicago Press: 741-780.

Woodbury, Stephen A. 1983. "Substitution Between Wage and Nonwage Benefits." American Economic Review, Vol. 73, No. 1, (March), pp. 166-182.

Woodbury, Stephen A. and Wei-Jang Huang. 1991. The Tax Treatment Of Fringe Benefits. Kalamazoo: The Upjohn Institute.

Zeldes, Stephen P. 1989a. "Consumption and Liquidity Constraints: An Empirical Investigation". Journal of Political Economy 97(2): 305-346.

. 1989b. "Optimal Consumption with Stochastic Income: Deviations from Certainty Equivalence". Quarterly Journal of Economics 104: 275-298. 